\title{
Exchange of nitrous oxide within the Hudson Bay lowland
}

\author{
C. L. Schiller and D. R. Hastie \\ Department of Chemistry and Centre for Atmospheric Chemistry, York University, North York, Ontario, \\ Canada
}

The source strength of atmospheric trace gases from natural ecosystems must be quantified in order to assess the effect of such inputs on the background tropospheric chemistry. A static chamber technique and a gas exchange technique were used to determine the emissions of nitrous oxide from five sites within the Hudson Bay Lowland, as part of the Northern Wetland Study. Two mechanisms, one diffusive and the other episodic, were found likely to be responsible for the emissions of nitrous oxide. The annual diffusive flux ranged from $-3.8 \mathrm{mg}\left(\mathrm{N}_{2} \mathrm{O}\right) / \mathrm{m}^{2}$ in a treed bog to $7.9 \mathrm{mg}\left(\mathrm{N}_{2} \mathrm{O}\right) / \mathrm{m}^{2}$ in an open fen. The addition of the episodic flux, increased this range to $-2.1 \mathrm{mg}\left(\mathrm{N}_{2} \mathrm{O}\right) / \mathrm{m}^{2}$ and $18.5 \mathrm{mg}\left(\mathrm{N}_{2} \mathrm{O}\right) / \mathrm{m}^{2}$ respectively. These episodic emissions occurred in from $2.5 \%$ to $16.7 \%$ of the samples during the late summer peak emission period. Since the gas exchange rate could not detect the episodic emissions, it was found to be a poor method for water emission rate determination within the wetland. LANDSAT-Thermatic Mapper (TM) imagery was used to scale the emissions, from the chamber level to an integrated average over the entire Hudson Bay Lowland. The total emission rate of $\mathrm{N}_{2} \mathrm{O}$ from the Hudson Bay Lowland, was determined to be $1.2 \mathrm{Gg}\left(\mathrm{N}_{2} \mathrm{O}\right) /$ year, of which $80 \%$ was attributed to episodic emissions.

\section{INTRODUCTION}

Nitrous oxide $\left(\mathrm{N}_{2} \mathrm{O}\right)$ is an important atmospheric trace gas, because of its role in greenhouse warming [Ramanathan et al., 1985 ] and as the major source of $\mathrm{NO}_{\mathrm{x}}$ in the stratosphere. Polar ice core samples indicate that the concentration of $\mathrm{N}_{2} \mathrm{O}$ had remained relatively constant before the 1800's, at around 285-289 ppbv [Pearman et al., 1986], while in 1989 its concentration was determined to be $310 \mathrm{ppbv}$ [Prinn et al., 1990], which constitutes an increase of $8.7 \%$. In measurements that span a 10 year period, 1978 to 1988, Prinn et al. [1990] showed that the concentration of atmospheric $\mathrm{N}_{2} \mathrm{O}$ has been increasing globally, at a rate of 0.25 to $0.31 \%$ per year over that period.

At present, there are a number of conflicting global budget estimates for $\mathrm{N}_{2} \mathrm{O}$. The most variability is in the estimated source strength which has been estimated to be, in $\mathrm{Tg}$ $\left(\mathrm{N}_{2} \mathrm{O}\right)$ /year, 31 to 210 [Banin, 1986], $48.1 \pm 21$ [McElroy and Wofsy, 1986], 50.0 to 206.5 [Warnick, 1988], 24.8 [Davidson, 1991] and $44 \pm 22$ [Mosier and Schimel, 1991]. The only known sink for $\mathrm{N}_{2} \mathrm{O}$ is stratospheric photolysis and reaction, and therefore the sink term for the budget remains relatively well defined at approximately $33.3 \mathrm{Tg}\left(\mathrm{N}_{2} \mathrm{O}\right)$ /year [McElroy and Wofsy, 1986]. This is lower than most of the source estimates, so many additional sinks have been postulated. Most of these have been found to be unimportant, for example, the reaction of $\mathrm{N}_{2} \mathrm{O}$ with $\mathrm{OH}$ radicals [Biermann et al., 1976]. Plants and biological systems present a complicated picture. Seiler et al. [1978] showed that growing plants were neither sources nor sinks of nitrous oxide, however, Blackmer and Bremner [1976] demonstrated in laboratory studies that soils had the ability to uptake $\mathrm{N}_{2} \mathrm{O}$. Ryden [1981] found that under certain soil conditions, grasslands could be a sink for $\mathrm{N}_{2} \mathrm{O}$ and Cicerone [1989] and Blackmer and Bremner [1976] postulated that swampy anaerobic soils may act as a sink for $\mathrm{N}_{2} \mathrm{O}$. Flux measurements for $\mathrm{N}_{2} \mathrm{O}$ indicate that wetland environments are a small source [Smith et al., 1983; Goodroad and Keeney, 1984], at least in wetlands which contain a large supply of nitrate, which has been

Copyright 1994 by the American Geophysical Union.

Paper number 93JD01358.

0148-0227/94/93JD-01358\$05.00 shown to inhibit the reduction of $\mathrm{N}_{2} \mathrm{O}$ to $\mathrm{N}_{2}$ [Blackmer and Bremner, 1976].

In this paper we report chamber measurements of the $\mathrm{N}_{2} \mathrm{O}$ flux within wetland ecosystems and vegetation classes, over the ice free thaw season of 1990, in the Hudson Bay lowland (HBL), Canada. The HBL is the second largest continuous peatland area in the world [Riley, 1982], and is covered from 75 to $100 \%$ by wetland [National Wetland Working Group(NWWG), 1986]. In addition, a static chamber technique and a gas exchange technique, for the determination of the emission rates of $\mathrm{N}_{2} \mathrm{O}$ from water, are compared. We determine an integrated annual emission flux for individual ecosystems, examine the effect of ecological succession along a transect from the coast of the James Bay to Kinosheo Lake and estimate a total annual $\mathrm{N}_{2} \mathrm{O}$ emission from the HBL.

\section{EXPERIMENT}

\section{Sites}

Nitrous oxide flux measurements were made at five sites within the Hudson Bay lowland, during the thaw period of June to October 1990 . The five sites were located along a line from North Point $\left(51^{\circ} 30.1^{\prime} \mathrm{N}\right.$ and $\left.80^{\circ} 28.1^{\prime} \mathrm{W}\right)$ to Kinosheo Lake $\left(51^{\circ} 33.0^{\prime} \mathrm{N}\right.$ and $\left.80^{\circ} 49.5^{\prime} \mathrm{W}\right)$. These sites were comprised of distinct ecosystem types, which were, in turn, represented by a number of distinctive vegetative classifications, chosen to obtain a comprehensive representation of the HBL. For a more complete description of the sites, refer to Roulet et al. [this issue].

\section{Methodology}

The static chamber technique was used to determine the $\mathrm{N}_{2} \mathrm{O}$ fluxes from soil and water surfaces. The static chamber technique is routinely used for the determination of $\mathrm{N}_{2} \mathrm{O}$ fluxes from terrestrial systems [Shepherd et al. 1991; Bowden et al. 1991; Matson et al. 1990], however, this technique is less popular for aquatic systems. The procedure determines the flux from the rate of change of the concentration in a constrained volume, over a given area. The flux determined by this method can be affected by the presence of the chamber (i.e. internal warming of the chamber, change in the concentration gradient at the surface). Denmead [1979] found that the measured emission rate of $\mathrm{N}_{2} \mathrm{O}$ from soils decreased as the measurement time increased. He attributed this to the increasing concentration within the chamber 
lowering the concentration gradient within the air in the soil. However, these experiments were on soils with high fluxes, so that the concentration increase within the chamber was of the order of 100 times the ambient concentration. This effect would not be important for $\mathrm{N}_{2} \mathrm{O}$ dissolved in water, since the water would be free to move between the chamber and the outside. Jury et al. [1982] also evaluated the method and concluded that at high emission rates the chamber method would underestimate the emissions from soils. They also found that the lower the air content of the soil (higher water saturation) the less effect the chamber had on the measured emission rates. Therefore in a wetland environment, where the soil is highly water saturated and the emission fluxes are relatively low, the chamber would be expected to have little effect on the emission rates for $\mathrm{N}_{2} \mathrm{O}$, provided the exposure time was such that the gas phase $\mathrm{N}_{2} \mathrm{O}$ increase was low.

In our application of the static chamber technique, 20-L chambers, made from plastic water bottles with the bottom removed, were placed into an approximately $5-\mathrm{cm}$ deep cuts in the bog surface. Cutting the surface was found to cause less disturbance than pushing the chambers into place. Each chamber covered an area of $550 \mathrm{~cm}^{2}$, and the height of the chamber was measured at placement to determine the exact volume. For use over water, chambers were modified to float on the surface and extend approximately $2 \mathrm{~cm}$ below the surface. The tops of the chambers were closed with a rubber septum, which permitted the extraction of a sample through a syringe needle into a $22-\mathrm{ml}$ Vacutainer (Becton-Dickinson), which had previously been evacuated. The chambers were shaded by aluminum foil to reduce heating of the air and the soil surface within the chamber. The ambient air temperature and a soil temperature profile or water temperature were measured for each vegetative site simultaneously with the emission measurements. Previous static chamber measurements have shown that at low concentrations the increase in the concentration with time is linear [Shepherd et al., 1991] and theref, re to minimize the number of analyses, only two air samples were taken from the chamber for each flux determination. Sample collection times ranged from 2 to 24 hours, with a median time of 3.5 hours, taken at various times throughout the day but generally restricted to morning and afternoon runs.

The emissions of $\mathrm{N}_{2} \mathrm{O}$ from water were also determined by a gas exchange technique. The difference between the concentration of $\mathrm{N}_{2} \mathrm{O}$ in water and that expected from the ambient air concentration and Henry's law drives the exchange of $\mathrm{N}_{2} \mathrm{O}$. The magnitude of the flux is then determined from this concentration gradient and the gas exchange rate which is obtained from a water-air boundary layer model.

The concentration of $\mathrm{N}_{2} \mathrm{O}$ in water was determined on a $15-\mathrm{ml}$ sample of water from a pond collected in the same 22-ml Vacutainers (Becton-Dickinson) as used for the static chamber method. Temperature and wind speed (as half-hour averages at $1-m$ height) were measured for each sample. Any biological activity in the water was stopped by the addition of $1 \mathrm{ml}$ of $1 \mathrm{M}$ $\mathrm{HCl}$ to the container. The samples were then returned to the lab for analysis. When in the lab, the headspace was filled to atmospheric pressure with ultra high pure (UPH) helium (99.999\%). The sample was then vigorously shaken for $5 \mathrm{~min}$. and allowed to sit for a half hour before the headspace gas was analyzed for $\mathrm{N}_{2} \mathrm{O}$.

All gas phase $\mathrm{N}_{2} \mathrm{O}$ analyses, from the chambers or the headspace of water samples, were performed in the laboratory using a gas chromatograph with an electron capture detector.
Samples were analyzed by injecting a $150-\mu 1$ sample, using a dynatech precision gas-sampling syringe with a low-volume side port needle, into an HP 5890 series II gas chromatograph. Separation occurred on a 5' x 1/8" stainless steel column, packed with $45 / 60$ mesh 5A molecular sieve (Supelco), maintained at $250^{\circ} \mathrm{C}$. The carrier gas was a mixture of $5 \%$ methane in Argon, at a flow rate of $20 \mathrm{ml} / \mathrm{min}$. The sample was detected by a Nickel 63 electron capture detector at $350^{\circ} \mathrm{C}$. The nitrous oxide peak eluted at $2 \mathrm{~min}$, which was well separated from the oxygen and carbon dioxide peaks, which eluted at about $0.5 \mathrm{~min}$. Baseline to baseline integration of the peaks was performed by the HP 3365 Chemstation software on a Hewlett Packard computer.

The mixing ratio of nitrous oxide in a sample was determined by comparison of the peak areas of the sample with that of a 516 \pm 10 parts per billion by volume (ppbv) $\mathrm{N}_{2} \mathrm{O}$ in $\mathrm{N}_{2}$ standard (Scott Specialty gases). One standard was run for every five samples. The majority of the samples were analyzed once, but a number of samples were involved in repeat analysis. The precision was determined to be better than $2 \%$ in all cases and generally better than $1 \%$. Combined with the error in the standard, this gave an accuracy of $3 \%$ for each analysis.

One problem arose from a residual amount of $\mathrm{N}_{2} \mathrm{O}$ found in all of the Vacutainers after evacuation. Fortunately, 70 containers remained after the experiment and the contamination in a filled container was found to be constant at $67 \pm 7 \mathrm{ppbv}$. Since the flux was determined from the difference between two measurements, the absolute value of this contamination did not affect the calculated flux. However, the variation in the measured contamination increased the error in the flux measurements and accounted for the majority of the analytical error in the experiment. This problem has since been alleviated with the rinsing of the Vacutainers with UHP helium before final evacuation.

The nitrous oxide flux for the static chamber method, was calculated from the change in the gas phase $\mathrm{N}_{2} \mathrm{O}$ mixing ratio within the chamber over time ( $\Delta M . R . /$ time), using the following equation:

$$
F l u x_{N_{2} O}\left(n g\left(N_{2} O\right) / m^{2} / h\right)=\frac{\Delta M . R .}{\text { time }} * \frac{P V}{R T} * M_{N_{2} O} * \frac{1}{A}(1)
$$

where $P$ is the atmospheric pressure, $V$ the volume of the chamber, $R$ the universal gas constant, $T$ is the air temperature within the chamber, $M_{N_{2} \mathrm{O}}$ is the molecular weight of $\mathrm{N}_{2} \mathrm{O}$ and $A$ is the area of the soil surface covered by the chamber.

For the gas exchange technique, the concentration of $\mathrm{N}_{2} \mathrm{O}$ in the water was calculated from the headspace concentration using Henry's law. This value was corrected for the $\mathrm{N}_{2} \mathrm{O}$ that was in the helium above the water sample, and for the $1 \mathrm{ml}$ of $1 \mathrm{M} \mathrm{HCl}$ that was added. The flux of $\mathrm{N}_{2} \mathrm{O}$ from the water, was calculated using the gas exchange model of Liss and Merlivat [1986]. The flux is obtained from the piston velocity $\left(\mathbf{k}_{(\mathrm{T}) \mathrm{w}}\right)$ and the concentration difference between the air and the water:

$$
F l u x_{N_{2} O}=K_{\left(T_{w}\right.}\left(\frac{C_{a}}{H_{N_{2} O}}-C_{w}\right)
$$

where $H_{N_{2} O}$ is the Henry's Law coefficient for $\mathrm{N}_{2} \mathrm{O}, \mathrm{C}_{\mathrm{a}}$ is the concentration of $\mathrm{N}_{2} \mathrm{O}$ in ambient air (the seasonal average of 
$303 \pm 9$ ppbv), and $C_{w}$ is the water concentration of $\mathrm{N}_{2} \mathrm{O}$. The Henry's law coefficient was calculated from the mole fractional solubility of $\mathrm{N}_{2} \mathrm{O}$ in water, given below:

$$
H_{N_{2} \mathrm{O}}=\frac{x_{N_{2} O \rho_{H_{2} O}}}{M_{H_{2} O}}
$$

where $\rho_{\mathrm{H}_{2} \mathrm{O}}$ was the density of water and $x_{\mathrm{N}_{2} \mathrm{O}}$ the mole fractional solubility of $\mathrm{N}_{2} \mathrm{O}$ in water which was calculated at a given temperature by the equation

$$
x_{N_{2} \mathrm{O}}=e^{\left[\left(-180.950+13205.8 T^{-1}+20.0399 \ln T+0.0238544 T / 1.9872\right]\right.}
$$

given in the review paper by Wilhelm et al. [1977].

The equations for the piston velocity were dependent upon the wind speed, as shown by the experiments by Crusius and Wanninkhof [1991] on the gas exchange-wind speed relationship at low wind speeds with $\mathrm{SF}_{6}$. These studies found that the gas exchange rate increased linearly with wind speed but contained two break points. The first of these break points occurs at wind speeds of $3 \mathrm{~m} / \mathrm{s}$ and is due to the surface changing from smooth to having capillary waves. The second break point occurs with the introduction of breaking waves; however, the wind speeds required to generate these waves were not attained during this experiment. Therefore two equations were required and are as follows: for wind speeds $<3 \mathrm{~m} / \mathrm{s}$

$$
k_{w}=k_{600} * \frac{(600)^{65}}{\left(S c_{N_{2} O}\right)^{65}} \quad \text { where } K_{600}=0.76 u
$$

for wind speeds $>3 \mathrm{~m} / \mathrm{s}$

$$
k_{w}=k_{600} * \frac{(600)^{5}}{\left(S c_{N_{2} O}\right)^{5}} \quad \text { where } \quad k_{600}=5.6 u-14.4
$$

where $\mathrm{k}_{600}$ was the piston velocity for $\mathrm{SF}_{6}$ at a $\mathrm{Schmidt}$ number of 600 and $u$ the wind speed (meters per second). The Schmidt number $\left(S c_{\mathrm{N}_{2} \mathrm{O}}\right)$ for $\mathrm{N}_{2} \mathrm{O}$ was determined by the kinematic viscosity ( $\nu$ ) divided by the diffusion coefficient for $\mathrm{N}_{2} \mathrm{O}\left(D_{\mathrm{N}_{2} \mathrm{O}}\right)$ which was obtained from the review paper by Himmelblau [1964]. The kinematic viscosity was calculated using

$$
\nu=\frac{\eta_{N_{2} O}}{\rho_{H_{2} O}+0.033 \mathrm{~g} / \mathrm{ml}}
$$

where $\eta_{\mathrm{H}_{2} \mathrm{O}}$ denoted the viscosity of water and $\rho_{\mathrm{H}_{2} \mathrm{O}}$ the density of water, to which $0.033 \mathrm{~g} / \mathrm{ml}$ has been added as a correction for the dissolved salts.

For each vegetative site, emission measurements were obtained on 11 or 12 days spaced throughout the approximately 130-day thaw period of the Hudson Bay lowland. Of the approximately 1100 chamber measurements, 16 were discarded. These showed extremely high initial concentrations within the chamber and a very large uptake value. This was consistent with a release of $\mathrm{N}_{2} \mathrm{O}$ caused by the insertion of the chamber, rather than an actual deposition. This resulted in a total of 1084 chamber measurements and 163 gas exchange measurements, covering the 32 vegetative classifications within the five sites. Table $1 a$ summarizes the site locations, ecosystem classes, vegetative classes, the number of emission measurements made, as well as the number of chambers placed on each. The locations and the number of measurements made using the gas exchange are included in Table $1 b$.

\section{Remote Sensing}

To scale the in situ measurements to larger areas, it was necessary to determine the areas covered by each of the vegetative types. This was done using Landsat thermatic mapper (TM) imagery. The procedure is described in detail by Roulet et al. [this issue]. To examine the transect from North Point to Kinosheo Lake, high-resolution imagery was used which could differentiate between bogs (or fens) that were primarily land and those which contained a large percentage of water $(\approx 40 \%)$. This allowed identification of a total of 10 distinct ecosystem classes. However, to image the entire HBL, as was necessary in the determination of the emissions over larger areas, a lower resolution was used which could only distinguish six distinct classes. The emission fluxes and land areas were then used to give a total emission estimate for each of the four classifications of wetland (midboreal, high boreal, low subarctic, high subarctic $[N W W G, 1986])$ as well as an estimate for the entire HBL.

\section{RESUlts AND DISCUSSION}

\section{Variation in $\mathrm{N}_{2} \mathrm{O}$ Flux Within a Vegetation Type}

The $\mathrm{N}_{2} \mathrm{O}$ flux from a brown moss-vegetated area revealed that the standard deviation between three replicate chambers, on some days, was better than $15 \%$ (Figure 1). Hence the precision of the technique is better than $15 \%$, and the greater variation between replicate samples on most sites was not due to the measurement technique but to the natural spatial variability in the fluxes for $\mathrm{N}_{2} \mathrm{O}$.

In spite of the apparent homogeneity of single vegetative types, large spatial variations have been observed [Bowden et al., 1991; Shepherd et al., 1991; Cates and Keeney, 1987; Goodroad et al., 1984]. Figure 2 shows all of the individual measurements, made within the five sites. There were two distinct emission categories. The first, containing roughly $98 \%$ of the emissions, had emission fluxes generally below $10 \mu \mathrm{g}\left(\mathrm{N}_{2} \mathrm{O}\right) / \mathrm{m}^{2} / \mathrm{h}$. In this category, within an individual ecosystem and vegetative type, mean fluxes tend to correspond closely with median fluxes, having close to a normal distribution, with variations between chambers of the order of the mean/median value. These emission fluxes were attributed to a diffusive transport mechanism. The second group of emissions, seen in approximately $2 \%$ of the measurements, show high fluxes, in many cases 10 times higher than the majority of the flux measurements. The low frequency of these high fluxes indicates an episodic mechanism, which points possibly to ebullition.

Methane measurements in a variety of natural wetland systems [Wilson et al., 1989; Chanton and Martens, 1988; Bartlett et al., 1988; Devol et al., 1988] have shown that although bubbling does not have the same importance in all ecosystems, it does make a significant contribution to the emission of methane. It is therefore likely that in an ecosystem where ebullition of methane is likely to occur, nitrous oxide can also be emitted in this manner. However, during this field study, bubbles were not 
TABLE 1a. Ecological and Vegetative Classifications of the Five Sites Within the Hudson Bay Lowland Measured Using the Chamber Method

\begin{tabular}{|c|c|c|c|c|}
\hline Site & Ecosystem Type & $\begin{array}{c}\text { Vegetative or } \\
\text { Topographic } \\
\text { Site } \\
\end{array}$ & $\begin{array}{c}\text { Sample } \\
\text { Size* }\end{array}$ & $\begin{array}{c}\text { Number } \\
\text { of } \\
\text { Chambers }\end{array}$ \\
\hline Coastal marsh & marsh & depression & 16 & 2 \\
\hline $51^{\circ} 29.8^{\prime} \mathrm{N}$ & & ridge & 19 & 2 \\
\hline \multirow[t]{2}{*}{$80^{\circ} 28.1^{\prime} \mathrm{W}$} & & Menyanthes site & 22 & 2 \\
\hline & & graminoid site & 20 & 2 \\
\hline Coastal fen & treed fen & tamarack hollows & 31 & 3 \\
\hline $51^{\circ} 28.2{ }^{\prime} \mathrm{N}$ & & tamarack hummocks & 32 & 2 \\
\hline \multirow[t]{4}{*}{$80^{\circ} 37.0^{\prime} \mathrm{W}$} & pool & pond 19 & 32 & 3 \\
\hline & & pond 25 & 18 & 2 \\
\hline & open fen & strings with shrubs & 53 & 5 \\
\hline & & depressions with sedge & 53 & 5 \\
\hline Interior fen & treed bog & peat plateau & 32 & 3 \\
\hline $51^{\circ} 30.7^{\prime} \mathrm{N}$ & pool & pool 11 & 27 & 2 \\
\hline \multirow[t]{4}{*}{$80^{\circ} 52.8^{\prime} \mathrm{W}$} & & pool 12 & 24 & 2 \\
\hline & open fen & shrubs with carex & 47 & 4 \\
\hline & & C. Limosa and willow shrubs & 45 & 4 \\
\hline & & C. Limosa wet area & 34 & 3 \\
\hline Kinosheo Lake - & treed bog & forest & 42 & 4 \\
\hline Tower Site & lakes & pool 1 & 48 & 6 \\
\hline $51^{\circ} 33.0^{\prime} \mathrm{N}$ & pools & Pool 26 & 42 & 4 \\
\hline \multirow[t]{5}{*}{$81^{\circ} 49.5^{\prime} \mathrm{W}$} & black holes & black holes & 40 & 5 \\
\hline & open bog & hummocks with Sphagnum & 22 & 2 \\
\hline & & hollows with moss & 44 & 4 \\
\hline & & brown moss and carex & 44 & 4 \\
\hline & & kalmia and carex & 22 & 2 \\
\hline Kinosheo Lake - & conifer forest & spruce moss forest & 27 & 3 \\
\hline Leduc Site & shrub rich bog & hollows with lichen & 32 & 3 \\
\hline $51^{\circ} 35.3^{\prime} \mathrm{N}$ & & hummocks with lichen & 22 & 2 \\
\hline \multirow[t]{5}{*}{$81^{\circ} 47.0^{\prime} \mathrm{W}$} & black holes & black holes & 43 & 4 \\
\hline & open bog & brown moss & 36 & 3 \\
\hline & & green sphagnum & 34 & 3 \\
\hline & & red sphagnum and carex & 36 & 3 \\
\hline & & myrica, buckbean, and carex & 45 & 4 \\
\hline
\end{tabular}

* Total number of measurements obtained within each classification.

observed directly or collected, therefore we cannot conclusively state that these high episodic fluxes were due to ebullition. The seasonal, diurnal, and temperature dependencies on emission fluxes were examined using the diffusive component only, while the episodic emission rates will be discussed later in this section.

The diffusive flux variability within a particular vegetation type varies with the vegetative type, possibly indicating the degree of nonhomogeneity of the site, despite outward appearances. Some of this variability can be attributed to physical characteristics. For example, the fluxes from hummocks showed a much higher variability than those from the hollows. This may be explained by the moderating effect of water, which varies less in the hollows than within the hummocks. However, in other cases, no clear physical reason for the large variability could be found. 
TABLE $1 b$. Comparison of the Emission of $\mathrm{N}_{2} \mathrm{O}$ From Water Using the Chamber Method and Gas Exchange Method During the 36- day Overlap Period, June 25 to July 31, 1990

\begin{tabular}{|c|c|c|c|c|}
\hline \multirow[b]{2}{*}{ Pool } & \multicolumn{2}{|c|}{ Chamber Method } & Gas Exchange & Method \\
\hline & $\begin{array}{c}\text { Mean (Median) Emission } \\
\mu \mathrm{g} / \mathrm{m}^{2} / \mathrm{hr}\end{array}$ & Number & $\begin{array}{c}\text { Mean (Median) Emission } \\
\mu \mathrm{g} / \mathrm{m}^{2} / \mathrm{h}\end{array}$ & Number \\
\hline \multicolumn{5}{|c|}{ Kinosheo Lake - Tower Site } \\
\hline 1 & $1.8(1.5)$ & 33 & $0.3(0.1)$ & 12 \\
\hline 2 & NA & NA & $0.9(0.3)$ & 5 \\
\hline 6 & NA & NA & $0.3(0.1)$ & 12 \\
\hline 7 & NA & NA & $0.3(0.0)$ & 11 \\
\hline 8 & NA & NA & $0.8(0.1)$ & 11 \\
\hline 9 & NA & NA & $0.5(0.5)$ & 1 \\
\hline 10 & NA & NA & $0.5(0.3)$ & 17 \\
\hline 26 & $-0.5(-0.4)$ & 24 & NA & NA \\
\hline \multicolumn{5}{|c|}{ Coastal Fen } \\
\hline 11 & $-0.4(0.0)$ & 18 & $8.1(2.7)$ & 8 \\
\hline 12 & $0.8(0.4)$ & 12 & $2.0(0.6)$ & 8 \\
\hline 13 & NA & NA & $2.3(1.4)$ & 8 \\
\hline 14 & NA & NA & $3.8(1.9)$ & 8 \\
\hline 15 & NA & NA & $2.7(0.5)$ & 8 \\
\hline 16 & NA & NA & $3.8(2.5)$ & 8 \\
\hline 17 & NA & NA & $3.9(1.8)$ & 8 \\
\hline 18 & NA & NA & $3.3(2.7)$ & 5 \\
\hline \multicolumn{5}{|c|}{ Interior Fen } \\
\hline 19 & $5.1(3.4)$ & 12 & $3.3(0.5)$ & 3 \\
\hline 20 & NA & NA & $2.7(0.4)$ & 4 \\
\hline 21 & NA & NA & $3.8(0.2)$ & 9 \\
\hline 22 & NA & NA & $1.8(1.2)$ & 9 \\
\hline 23 & NA & NA & $-0.3(0.1)$ & 4 \\
\hline 24 & NA & NA & $2.4(0.8)$ & 4 \\
\hline 25 & $1.5(3.2)$ & 12 & NA & NA \\
\hline
\end{tabular}

NA, Data not available.

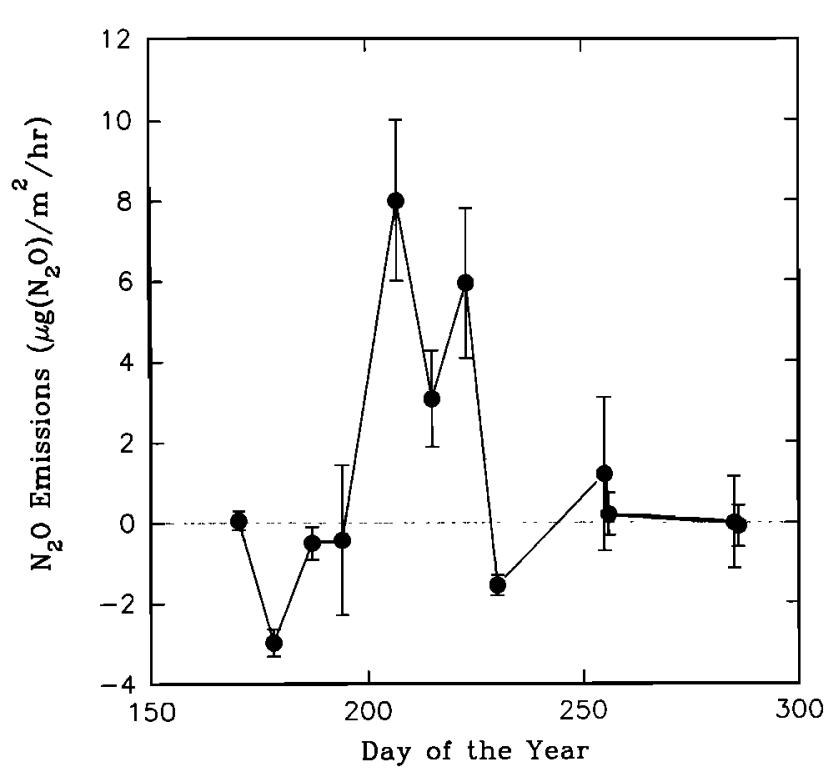

Fig. 1 The $\mathrm{N}_{2} \mathrm{O}$ emission rate from a brown moss site within the Leduc Site. The error bars indicate the standard deviation of triplicate chambers within this vegetative site.

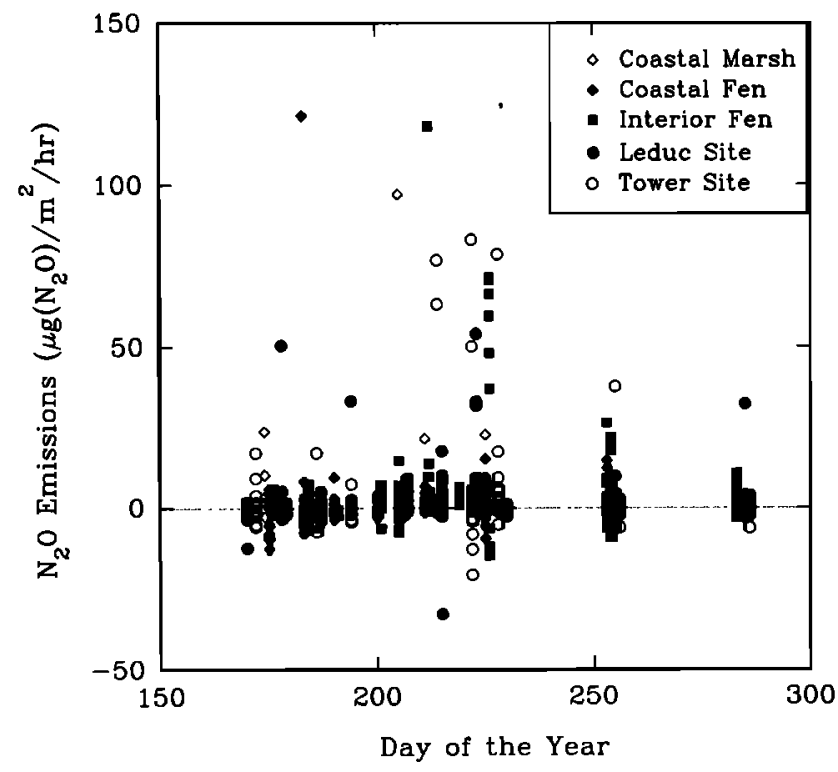

Fig. 2 Emission rates of $\mathrm{N}_{2} \mathrm{O}$ from all five sites within the Hudson Bay lowland, June to October 1990. 
Whatever the cause of the variations, they placed constraints on the ability to undertake process type experiments and the determination of "representative" fluxes. The variations observed were so large that it proved almost impossible to examine the dependence of the emission of $\mathrm{N}_{2} \mathrm{O}$ on any external parameters. To determine a representative flux, for a particular vegetative type, it was necessary to make a large number of measurements at a number of locations to integrate over the spatial variability in the $\mathrm{N}_{2} \mathrm{O}$ sources. Thus we used as many chambers and as many measurements as logistical constraints would allow.

At all but the treed sites and pools, the diffusive fluxes showed a similar seasonal variation (e.g., Figure 3 ). There was a period of low emission or even uptake in the spring, followed by a rise to a maximum late in the summer and a decrease in the fall.

The seasonal variation for the treed bogs and treed fens was markedly different, as shown in Figure 4 . This shows an early season maximum, followed by a minimum during the warmest part of the growing season, which coincided with the maximum emission fluxes observed at other vegetative areas. There probably was significant uptake occurring at these treed sites during the growing season. The seasonal variation for the pools will be discussed in a later section.

To examine the diurnal variation, the flux was measured as a function of time on two vegetative classes at the Kinosheo Lake tower site. Chambers were placed on collars that were fixed in the ground, so exactly the same area of bog was studied. Figures $5 a$ and $5 b$ show the results for one of these two vegetation types on July 21 and August 12 . There was no consistent diurnal pattern in the emission flux and no correlation with soil temperature similar to Blackmer et al. [1982], who suggest that the diurnal relation changes with changing water content.

The soil temperature dependence on the emission rate of $\mathrm{N}_{2} \mathrm{O}$ was examined, but with the exception of emissions from within lichen sites there appeared to be no correlation. At the lichen hummocks and hollows at the Kinosheo Lake Leduc site, $\mathrm{N}_{2} \mathrm{O}$ fluxes exhibited a dependence on the 5-cm soil temperature. Figure 6 shows the $\mathrm{N}_{2} \mathrm{O}$ fluxes increasing with soil temperature up to $25^{\circ} \mathrm{C}$, above which a decrease in the flux was observed.

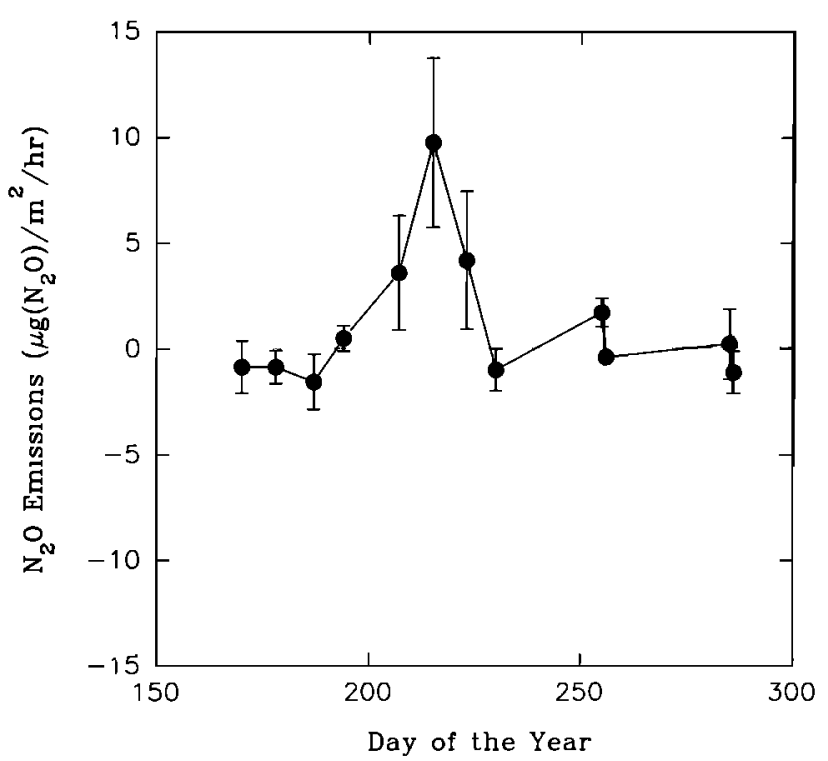

Fig. 3 Seasonal variation of the emissions of $\mathrm{N}_{2} \mathrm{O}$ from a black hole at the Leduc site, in the Hudson Bay lowland, from June to October 1990. The error bars indicate the standard deviation between chambers within the site.
This could be due to the temperature being too high for the microbes to function, or that at higher temperatures the balance between consumption and production may shift to lower the net output. This weak temperature dependence was likely masked, at other vegetative sites, by the larger spatial variability observed.

Surface vegetation has also been implicated in the transport of trace gases from soil systems [Rosswall et al., 1989]. The majority of the surface of the bogs and fens were covered with mosses and lichens, which are nonvascular, and would not be expected to act as a conduit of gas transport. However, when the fluxes from these areas were compared to those from areas containing a significant number of vascular plants, no significant differences were found. Therefore no conclusions on the importance of vascular plants, in the transport of $\mathrm{N}_{2} \mathrm{O}$, could be made.

The determination of an annual flux, even for a single vegetative site, is complicated by the effect of the episodic emissions. In many cases, these fluxes were 10 times higher than the diffusion-based means, and so contributed significantly to the total emission, even though they were only found in just over $2 \%$ of the chamber measurements. Since the flux at each vegetative site was only measured between 16 and 53 times, it is possible that the episodic emissions within a particular site may have been undersampled. For this reason we have calculated an annual flux in two ways. First, within each vegetation site, the average flux for a measurement day was calculated. These were then integrated over the 130-day thaw season to determine the annual emission rate of $\mathrm{N}_{2} \mathrm{O}$ from those sites. These results are listed in column 4 of Table 2 . Second, the same process was undertaken but with all the episodic emissions removed. This resulted in a diffusive emission only component, which is summarized in column 5 of Table 2. These diffusive emissions are, in general, low, with about one third indicating net uptake rather than emission. An episodic flux was then determined. The fraction of all chamber measurements showing episodic emissions $\left(X_{\text {Episodic }}\right)$ in the 14-day period, peaking at the end of the intensive field study, was determined. To account for the lack of measurements

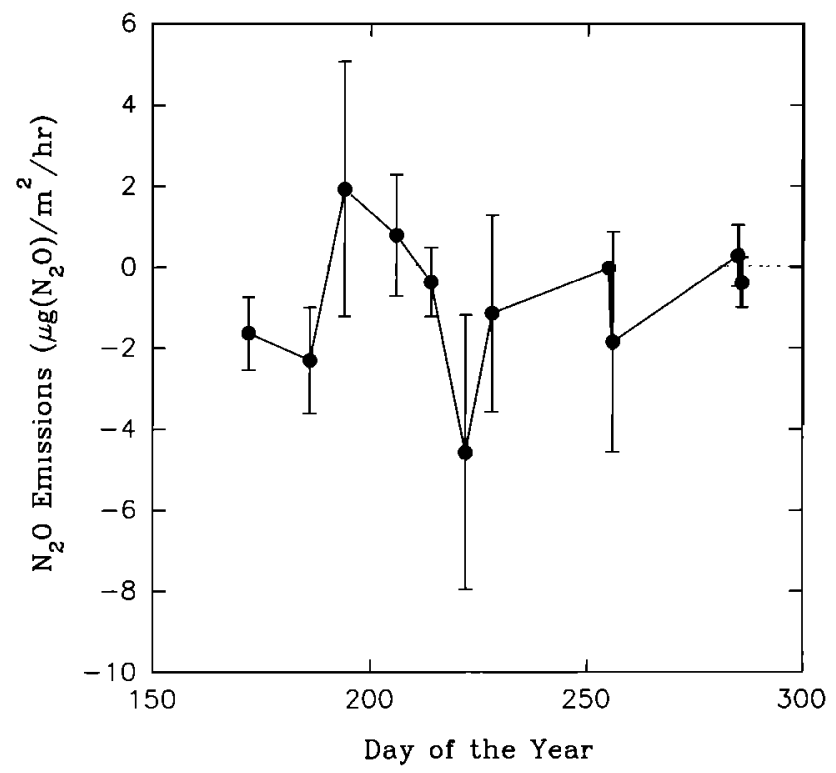

Fig. 4 Seasonal variations of the emissions of $\mathrm{N}_{2} \mathrm{O}$ from a treed bog site at the Kinosheo Lake tower site, from June to October 1990 . The error bars indicate the standard deviation between chambers within the site. 

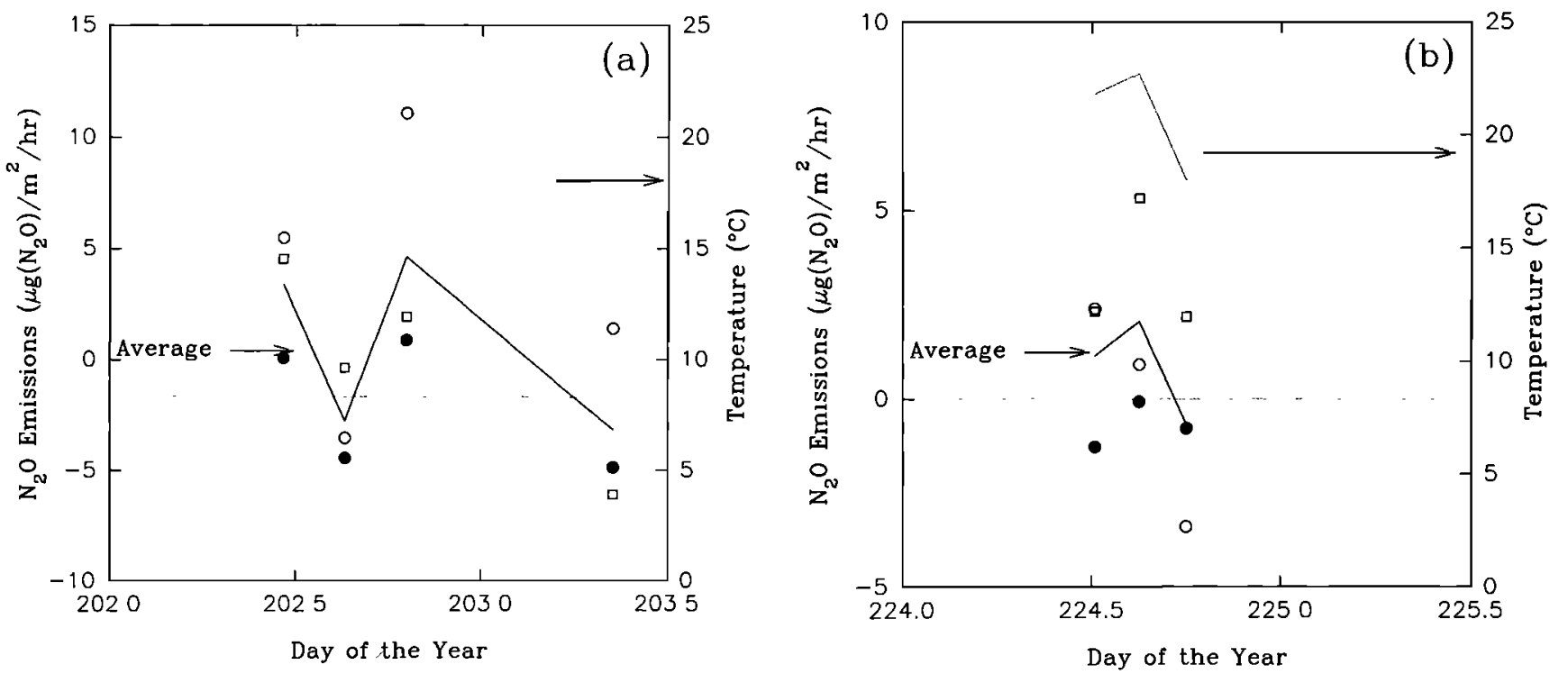

Fig. 5 Emissions of $\mathrm{N}_{2} \mathrm{O}$ as a function of time of day from three chambers, measured on (a) July 21 and (b)August 12. Ambient temperatures on those days are presented as dotted lines.

after the 14-day peak period, it was assumed that this frequency of episodic fluxes continued for a total of 30 days $(t)$. Table 3 contains the average episodic flux for each site as well as the percentage of episodic emissions that occurred during the 14-day period. The episodic flux for each vegetative class was calculated from

$$
F_{\text {Episodic }}=E_{\text {Epsodic }} * X_{\text {Epsodic }} * t
$$

where $E_{\text {Episodic }}$ was the average magnitude of the episodic fluxes at a given site. This episodic flux was added to the annual diffusive flux to give the values in column 6 of Table 2 . The inclusion of episodic emissions, for sites where none was observed, resulted in all emission fluxes becoming positive. Due to the low number of episodic events measured per vegetation type at any given site, it was impossible to examine whether or not there was a difference in the episodic emissions at the vegetation level.

An important observation from the diffusive emissions was that approximately $34 \%$ of the vegetative sites show net uptake. Cicerone [1989] and Blackmer and Bremner [1976] have postulated that a wetland could be a sink for $\mathrm{N}_{2} \mathrm{O}$, but measurements in temperate wetlands have indicated that these wetlands act as sources rather than sinks [Smith et al., 1983; Goodroad and Keeney, 1984]. However, in grasslands [Ryden, 1981] and in temperate forests [Bowden et al., 1991], uptake of $\mathrm{N}_{2} \mathrm{O}$ has been shown to occur. In a particularly nitrogen deficient region, processes capable of utilizing atmospheric $\mathrm{N}_{2} \mathrm{O}$ become viable, resulting in the uptake of $\mathrm{N}_{2} \mathrm{O}$ [Rosswall et al., 1989]. In the HBL there is clear evidence for both production and consumption of $\mathrm{N}_{2} \mathrm{O}$, and while the episodic emissions result in net emission of $\mathrm{N}_{2} \mathrm{O}$, there are times and locations where $\mathrm{N}_{2} \mathrm{O}$ uptake is occurring.

Ecosystem level variations in the emissions of $\mathrm{N}_{2} \mathrm{O}$. In order to scale up the annual emission fluxes determined from the chamber measurements to the ecosystems distinguishable by the Landsat TM remote sensing, the fluxes from the various vegetation types were combined into the ecosystem types given in Table $1 a$. The large differences in the $\mathrm{N}_{2} \mathrm{O}$ fluxes from different vegetative types, within a given ecosystem type, presented problems in averaging. For example, fluxes from strings with shrubs in an open fen exhibited a small uptake, while the adjacent depressions with sedges produced a significant positive flux. The open fen flux then depends upon the fraction of each vegetative type in the ecosystem. In such cases, visual examination over a wide area was used to estimate the fractions. An approximately equal weighting of vegetative types was observed for all ecosystems, so that a simple average was used to determine the emission flux. Table 4 contains the calculated annual emission flux of $\mathrm{N}_{2} \mathrm{O}$ for the individual ecosystems at the various sites. Since both the diffusive emission component and the total emission could be used to examine ecosystem level characteristics, the diffusive component was used due to its larger sample size.

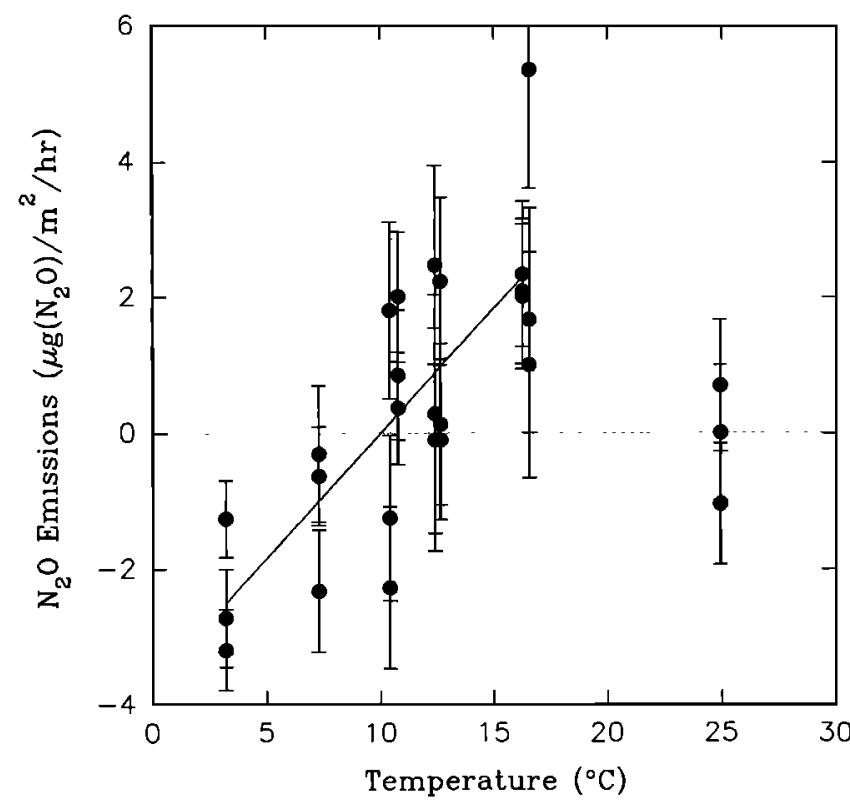

Fig. 6 Dependence of the emission rate of $\mathrm{N}_{2} \mathrm{O}$ upon soil temperature (5 $\mathrm{cm}$ ), within a shrub rich bog area at the Kinosheo Lake Leduc site $\left(r^{2}=0.77\right)$ 
TABLE 2. The Emissions of $\mathrm{N}_{2} \mathrm{O}$ from the Various Vegetative Classifications Within the Hudson Bay Lowland

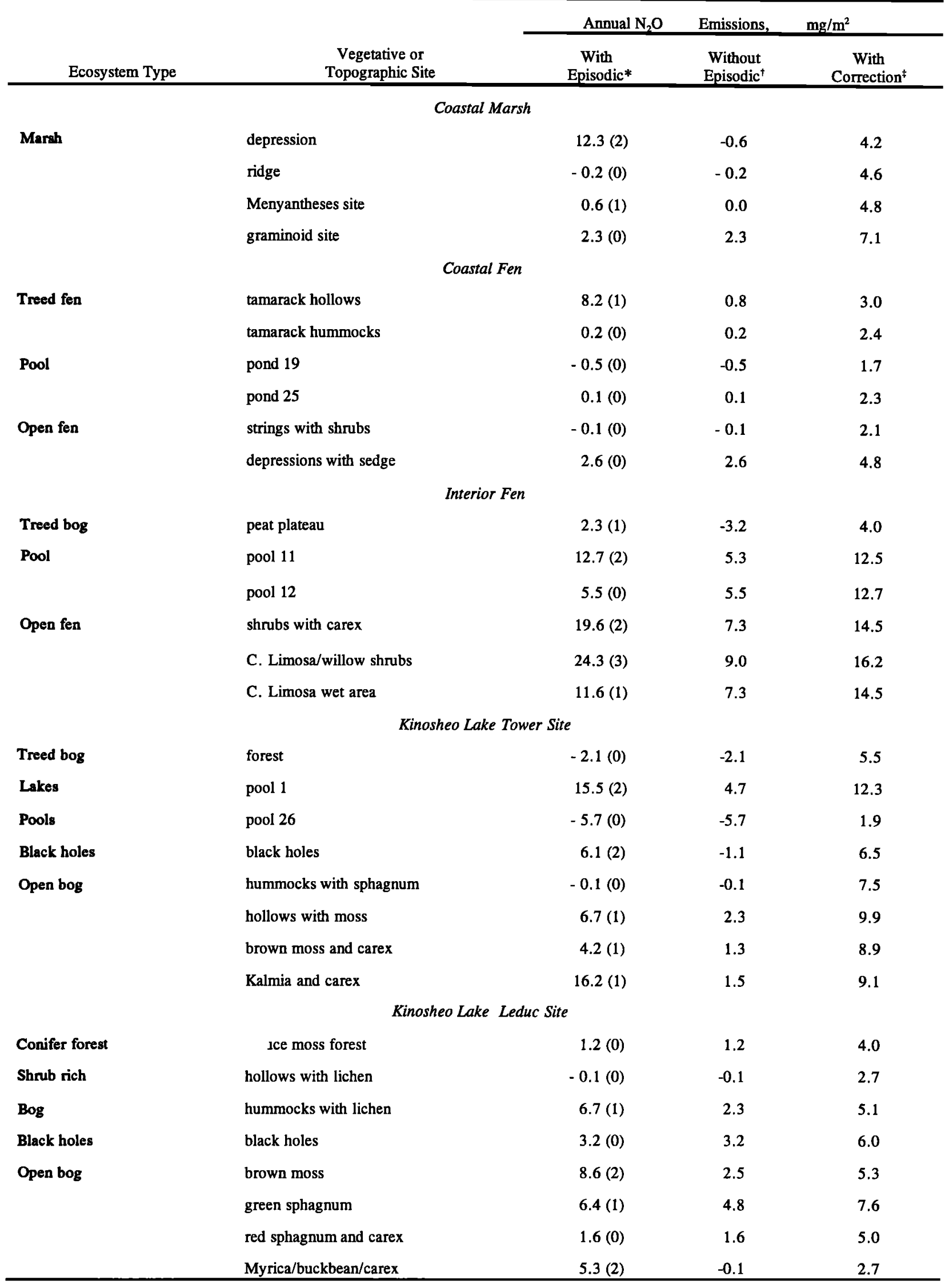

Numbers in parentheses in column 4 refer to the number of samples in which high episodic emissions occurred.

* Annual $\mathrm{N}_{2} \mathrm{O}$ emissions which included the high-emission episodic events.

$\dagger$ Annual $\mathrm{N}_{2} \mathrm{O}$ emissions which did not include the high-emission episodic events.

¥ A correction for possible undersampling of the episodic emissions. 
TABLE 3. The Average Emission Rate and Percentage of Episodic Emissions Occurring at Each Site

\begin{tabular}{lccc}
\hline \multicolumn{1}{c}{ Site } & $\begin{array}{c}\text { Average Episodic } \\
\text { Emission Rate } \\
\mu \mathrm{g} / \mathrm{m}^{2} / \mathrm{h}\end{array}$ & $\begin{array}{c}\text { Percentage of } \\
\text { Episodic Emissions } \\
\text { Over } \\
130 \text { Days }\end{array}$ & $\begin{array}{c}\text { Percentage of } \\
\text { Episodic Emissions } \\
\text { Over } \\
30 \text { Days }\end{array}$ \\
\hline Coastal marsh & 35.5 & 3.9 & 18.7 \\
Coastal fen & 121.0 & 0.5 & 2.5 \\
Interior fen & 60.0 & 4.3 & 16.7 \\
Kinosheo Lake-tower site & 39.0 & 2.3 & 10.0 \\
Kinosheo Lake-Leduc site & 67.0 & 2.2 & 7.2 \\
\hline
\end{tabular}

Within an individual site, a qualitative examination of the emissions revealed that annual fluxes from treed areas were always lower than those from the open fen and open bog areas. The fluxes from the pools were also lower than those from the open bog and fen areas but not always higher than those from the treed areas.

There were significant differences in the emission fluxes from similar ecosystems at different sites. For example, in the open fens, the emission fluxes were almost a factor of 10 higher at the interior fen than at the coastal fen. This large variation was also seen between the pool ecosystems at these two sites. These differences between ecosystem types, that were indistinguishable by remote sensing, could be larger than the differences between emissions from ecosystems which were clearly distinct to remote sensing. This indicates that extreme care must be used in using ecosystem classifications to scale up the emission rates of $\mathrm{N}_{2} \mathrm{O}$ from the chamber level to a large scale, as would be seen by remote sensing.

Once the emission rates of $\mathrm{N}_{2} \mathrm{O}$ had been determined at the ecosystem level, they required further modification in order to scale up to the transect level resolution of the Landsat TM remote sensing. While the resolution of the Landsat TM was sufficient to identify the differences between a bog and a bog with a significant portion of its surface covered with pools, it did not have the resolution to determine the percentage of surface water for each of the wetland types. Color air photography determined that the percentage of water in the bog with pool areas and the fen with pool areas was $40 \%$. Similarly, black holes were found to cover roughly $20 \%$ of the open bog and shrub rich bog areas. Additional detail on the remote sensing and scaling up information is available in an accompanying paper by Roulet et al. [this issue].

The ecosystems at the five sites were combined into 10 remote sensing identifiably different classifications. A summary of the emission rates from the 10 classifications as well as the equations used to determine these rates are summarized in table 5. The qualitative trend in emission rates, evident from these data was: treed bogs < open bogs with pools < treed fens < open bogs $<$ open fens with pools $<$ open fens.

A comparison of emission rates of $\mathrm{N}_{2} \mathrm{O}$, at the ecosystem level in the HBL, with those from comparable natural ecosystems, revealed a similar range for the emission rates. The mean thaw season emission rate of $0.41 \mu \mathrm{g}\left(\mathrm{N}_{2} \mathrm{O}\right) / \mathrm{m}^{2} / \mathrm{h}$, from our conifer forest at the Leduc site, was comparable to the 0.53 $\mu \mathrm{g}\left(\mathrm{N}_{2} \mathrm{O}\right) / \mathrm{m}^{2} / \mathrm{h}$ at a pine site observed by Bowden et al. [1991] at a forest site in Massachusetts. In addition, this site observed uptake, which was also observed in the treed areas in this study.
TABLE 4. Annual Emission Rate of $\mathrm{N}_{2} \mathrm{O}$ From the Ecosystems Within the Hudson Bay Lowland

\begin{tabular}{cccc} 
& Annual $\mathrm{N}_{2} \mathrm{O}$ & Emission & $\mathrm{mg} / \mathrm{m}^{2}$ \\
\cline { 2 - 4 } ECOSYSTEM & $\begin{array}{c}\text { With } \\
\text { Episodic* }\end{array}$ & $\begin{array}{c}\text { Without } \\
\text { Episodic }^{\dagger}\end{array}$ & $\begin{array}{c}\text { With } \\
\text { Correction }^{\ddagger}\end{array}$ \\
\hline
\end{tabular}

\section{Coastal Marsh}

$\begin{array}{llll}\text { Marshes } & 3.8 & 0.4 & 5.2\end{array}$

Coastal Fen

$\begin{array}{lrrr}\text { Open Fen } & 1.3 & 1.3 & 3.5 \\ \text { Treed Fen } & 4.2 & 0.5 & 2.7 \\ \text { Pools } & -0.2 & -0.2 & 2.0\end{array}$

$\begin{array}{lccc} & \text { Interior Fen } & & \\ \text { Open Fen } & 18.5 & 7.9 & 15.0 \\ \text { Treed Bog } & 2.3 & -3.2 & 4.0 \\ \text { Pools } & 9.1 & 5.4 & 12.6\end{array}$

Kinosheo Lake Tower Sice

$\begin{array}{lccr}\text { Open Bog } & 6.8 & 1.3 & 8.9 \\ \text { Treed Bog } & -2.1 & -2.1 & 5.5 \\ \text { Lakes } & 15.5 & 4.7 & 12.3 \\ \text { Pools } & -5.7 & -5.7 & 1.9 \\ \text { Black Holes } & 6.1 & -1.1 & 6.5\end{array}$

Kinosheo Lake Leduc Site

\begin{tabular}{llll} 
Open Bog & 9.2 & 2.2 & 5.2 \\
Conifer Forest & 1.2 & 1.2 & 4.0 \\
Shrub Rich Bog & 3.3 & 1.1 & 3.9 \\
Black Holes & 3.2 & 3.2 & 6.0 \\
\hline
\end{tabular}

* Annual $\mathrm{N}_{2} \mathrm{O}$ emissions which included the high-emission episodic events.

$\dagger$ Annual $\mathrm{N}_{2} \mathrm{O}$ emissions which did not include the high-emission episodic events.

$¥$ Correction for possible undersampling of the episodic emissions. 
TABLE 5. Annual Emission Rates of $\mathrm{N}_{2} \mathrm{O}$ From 10 Ecosystems Identified by Landsat TM Along a Transect From North Point to Kinosheo Lake

\begin{tabular}{|c|c|c|c|c|}
\hline & & Annual & $\begin{array}{c}\mathrm{N}_{2} \mathrm{O} \\
\mathrm{mg} / \mathrm{m}^{2}\end{array}$ & Emissions \\
\hline Ecosystem Type & Equation & $\begin{array}{l}\text { With" } \\
\text { Episodic }\end{array}$ & $\begin{array}{l}\text { Without }^{\dagger} \\
\text { Episodic }\end{array}$ & $\begin{array}{l}\text { With }^{\ddagger} \\
\text { Correction }\end{array}$ \\
\hline 1. Water & $\mathrm{E}_{\text {Lake }}$ & 15.5 & 4.7 & 12.3 \\
\hline 2. Marshes & $\mathrm{E}_{\text {Marsh }}$ & 3.8 & 0.4 & 5.2 \\
\hline 3. Open fen (OF) & $E_{O F}=\frac{\left(E_{O F_{F F}}+E_{O F_{F}}\right)}{2}$ & 9.8 & 4.6 & 9.2 \\
\hline 4. Open fen with pools (OFwP) & $E_{\text {OFWP }}-0.4 \frac{\left(E_{\text {Poot }_{W F}}+E_{\text {Pool }_{\sigma}}\right)}{2}+0.6 E_{\text {oF }}$ & 7.7 & 3.8 & 8.4 \\
\hline 5. Treed fen (TF) & $\mathrm{E}_{\mathrm{TP}}$ & 4.2 & 0.5 & 2.7 \\
\hline 6. Open bog (OB) & $E_{O B}=0.8 \frac{\left(E_{O B_{r}}+E_{O B_{L S}}\right)}{2}+0.2 \frac{\left(E_{B H_{r z}}+E_{B H_{L}}\right)}{2}$ & 7.3 & 1.6 & 6.9 \\
\hline 7. Open bog with pools (OBwP) & $E_{\text {OBWP }}=0.6 E_{O B}+0.4 E_{P O O L_{n}}$ & 2.1 & -1.3 & 4.9 \\
\hline 8. Shrub rich bog (SRB) & $E_{S R A}=0.8 E_{S R B_{L S}}+0.2 \frac{\left(E_{B H_{B}}+E_{B H_{B}}\right)}{2}$ & 3.6 & 1.1 & 4.4 \\
\hline 9. Treed bog (TB) & $E_{T B}=\frac{\left(E_{T B_{x B}}+E_{T B_{u s}}\right)}{2}$ & 0.1 & -2.7 & 4.8 \\
\hline 10. Conifer forest (CONF) & $\mathbf{E}_{\text {CONE }}$ & 1.2 & 1.2 & 4.0 \\
\hline
\end{tabular}

TM, thermatic mapper.

* Annual $\mathrm{N}_{2} \mathrm{O}$ emission rate which includes the high emission episodic events.

$\dagger$ Annual $\mathrm{N}_{2} \mathrm{O}$ emission rate which does not include the high emission episodic events.

¥ Correction for possible undersampling of the episodic emissions.

The emission from the coastal marsh of $1.3 \mu \mathrm{g}\left(\mathrm{N}_{2} \mathrm{O}\right) / \mathrm{m}^{2} / \mathrm{h}$ was on the low end of the emissions $\left(1.3\right.$ to $\left.29.5 \mu \mathrm{g}\left(\mathrm{N}_{2} \mathrm{O}\right) / \mathrm{m}^{2} / \mathrm{h}\right)$ measured from a salt marsh at Barataria Basin by Smith et al. [1983]. Measurements of $\mathrm{N}_{2} \mathrm{O}$ flux from a peat bog in northern Minnesota [Urban et al., 1988] showed emission rates ranging from $<0.63$ to $7.17 \mu \mathrm{g}\left(\mathrm{N}_{2} \mathrm{O}\right) / \mathrm{m}^{2} / \mathrm{h}$ which compared well with our open bog measurements of 2.3 and $3.1 \mu \mathrm{g}\left(\mathrm{N}_{2} \mathrm{O}\right) / \mathrm{m}^{2} / \mathrm{h}$. This indicated that mean emission rates of $\mathrm{N}_{2} \mathrm{O}$ measured from the Hudson Bay lowland were similar in magnitude to those rates measured from comparable natural ecosystems.

A comparison of the gas exchange versus the chamber technique. The emission of $\mathrm{N}_{2} \mathrm{O}$ from water was measured by the gas exchange and chamber techniques. Measurements made over a 36-day period allowed a comparison of the methods. Figure 7 contains all $\mathrm{N}_{2} \mathrm{O}$ emission flux measurements from water, over the entire thaw season, using both methods. A few very high fluxes are readily apparent while using the chamber method. As with the soil measurements, these occurred predominantly during the late summer or the spring thaw in only $2 \%$ of the chamber measurements and were likely due to the emission of bubbles. Table 2 contains the calculated annual emission rates using the chamber method, at all three sites. Of the six ponds measured only two showed these high episodic emissions occurring. In the two pools in which they were observed, the calculated annual emission rate for $\mathrm{N}_{2} \mathrm{O}$ more than doubled over the diffusive emissions.

A comparison of the two techniques on a single large pool (pool 1, area $>10,000 \mathrm{~m}^{2}$ ) is shown in Figure $8 a$. For the majority of the measurements the chamber method gave substantially higher fluxes than the gas exchange method, even when the very high episodic fluxes were not included. The mean emission rate from the gas exchange technique was 0.3 $\mu \mathrm{g}\left(\mathrm{N}_{2} \mathrm{O}\right) / \mathrm{m}^{2} / \mathrm{h}$ while that from the chamber method was 1.8 $\mu \mathrm{g}\left(\mathrm{N}_{2} \mathrm{O}\right) / \mathrm{m}^{2} / \mathrm{h}$. Similar comparisons with smaller pools $(<500$ $\mathrm{m}^{2}$ ) showed smaller differences between the methods. Pool 12 (19.4-m fetch) at the coastal fen (Figure 8b) and Pool 11 (24.1 $\mathrm{m}$ fetch) at the coastal fen (Figure $8 c$ ) showed no significant difference between the methods.

The large difference between the fluxes measured by the two techniques on the large pond may be explained in two ways. The 


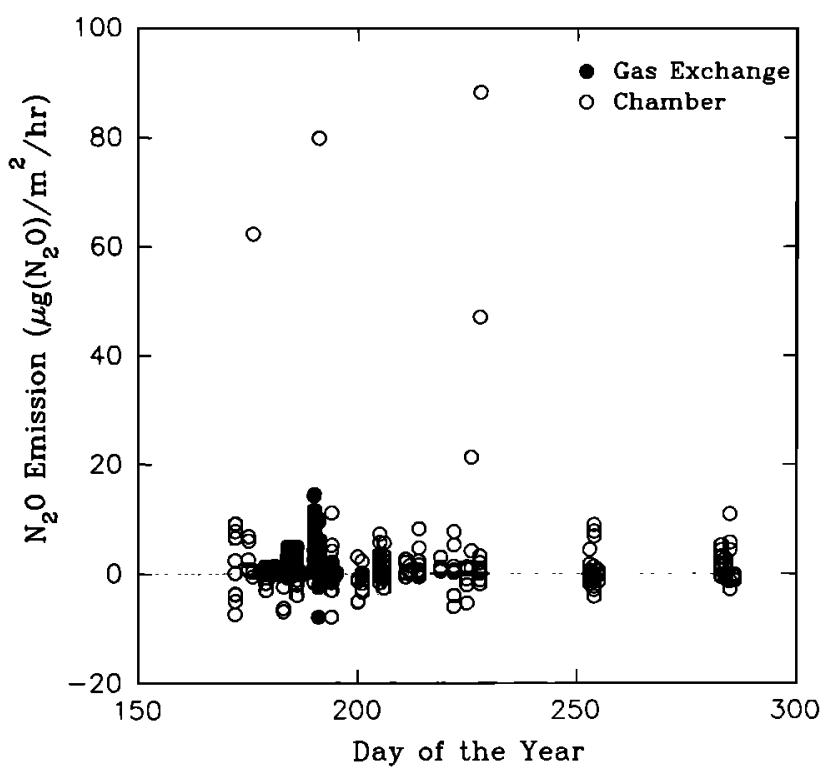

Fig. 7 Emission rates for $\mathrm{N}_{2} \mathrm{O}$ from water using gas exchange and chamber methods, from three sites within the Hudson Bay lowland, June to October 1990.

first may be the presence of small bubbles that would be detected by the chamber method but missed by the gas exchange technique. Another possible explanation was that using the wind speed obtained on land for the wind over a large lake would underestimate the emission fluxes from these larger ponds [Kwan and Taylor, 1993]. Using Figure 3 from Kwan and Taylor [1993], for pond 1 with its $165-\mathrm{m}$ fetch, gives a friction velocity based on a wind speed measured over land that would be approximately $30 \%$ smaller than that which would be measured over water. This would result in a $30 \%$ underestimate of the emission flux. However, this is not large enough to account for the $600 \%$ difference between the measured emission fluxes measured by the two methods. Therefore it appears that from these emission measurements the gas exchange technique underestimates emission fluxes from large pools compared to the chamber method.

In examining the results from the gas exchange and chamber methods, it was clear that because the episodic emissions account for a significant proportion of the total emissions, the most reliable method was the chamber method which captured these episodic emissions. We have therefore used only the chamber data in the determination of the total integrated emissions within the HBL. However, due to the faster time resolution the results from the gas exchange techniques were used for the examination of the variability of emission rates of $\mathrm{N}_{2} \mathrm{O}$ from water.

\section{Variability of $\mathrm{N}_{2} \mathrm{O}$ Emissions From Water}

Gas exchange measurements showed the flux of nitrous oxide was dependent on the position on the lake from which the sample was taken. Figure $9 a$ shows measurements made, on the same day, on pool 10 which was $230 \mathrm{~m}$ in length and approximately 2 $m$ deep in the center. It was one of the larger ponds and was permanent. Positions 1 and 5 indicate the sample taken from the north and south shore, respectively, with the other positions equally spaced along the length of the lake. These data showed higher nitrous oxide flux from the edge of a pond than from the middle. A similar result is shown in the chamber measurements from pool 1 (Figure 9b). This difference in the emission fluxes

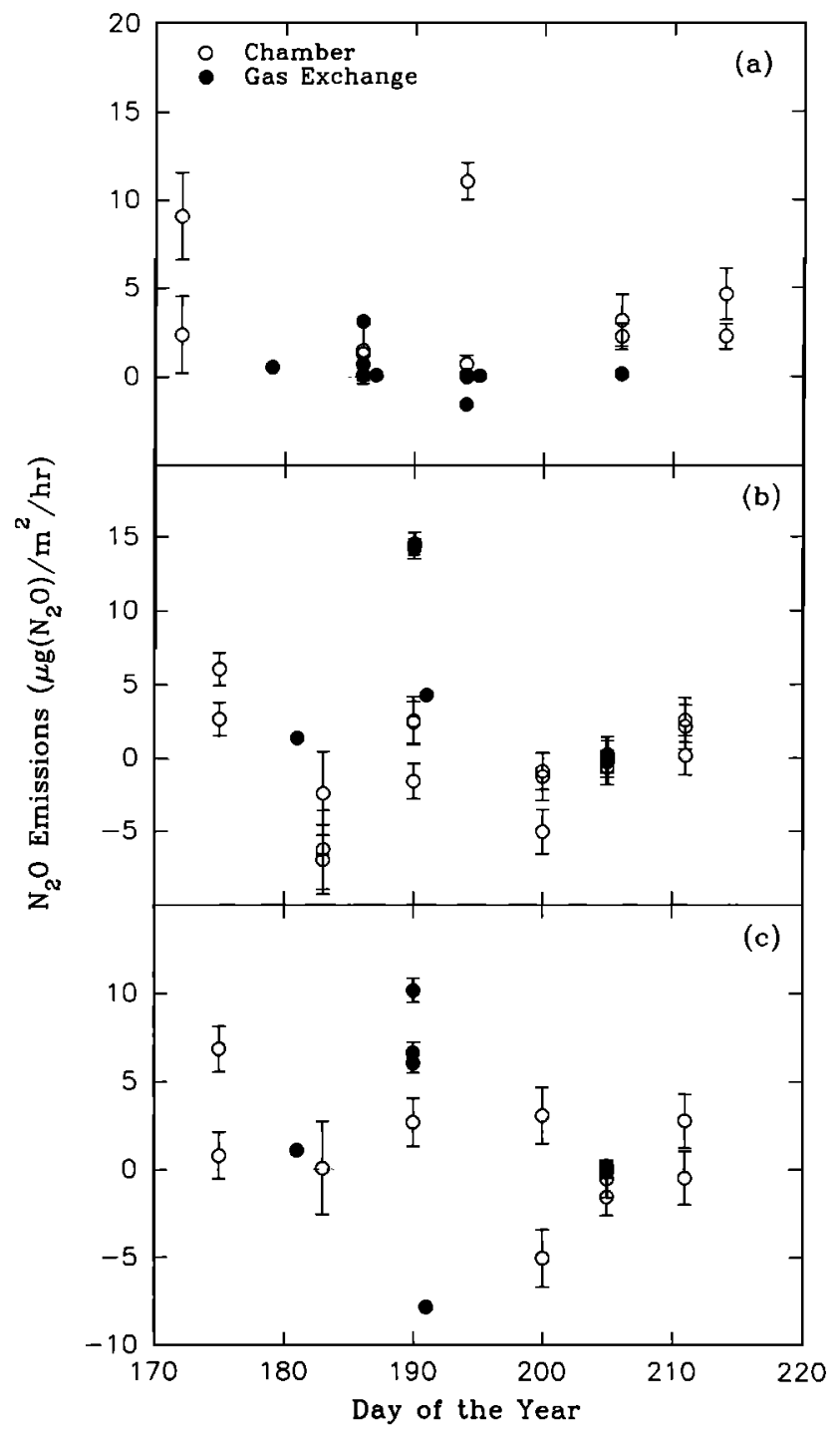

Fig. 8 Comparison of the gas exchange and chamber-determined emission rates at $(a)$ pool 1 at the Kinosheo Lake tower site, $(b)$ pool 11 at the coastal fen, and (c) pool 12 at the coastal fen.

from the edges of pools compared to those from the center could indicate a possible time lag in the production rates due to uneven heating of the bottom of the pools, or may be due to the difference in oxidative capacities of these two areas, thereby shifting the production/consumption balance.

Measurements taken on two different days, days 186 and 194, were used to examine diurnal variations of the fluxes from pools 1 and 7 at the Kinosheo Lake site. Just as the emission rate for $\mathrm{N}_{2} \mathrm{O}$ from land showed no consistent diurnal emission pattern, neither does it from water (Figures $10 a$ and $10 b$ ). However, unlike the land-based results, no distinct seasonal variation in the emission rates of nitrous oxide from these pools was found (Figures 7, 8a, 8b, and 8c).

As with the land, pools also showed uptake of $\mathrm{N}_{2} \mathrm{O}$. This was particularly important in the bog, where the pool uptake was substantial.

A comparison of the emission fluxes from different sites indicated that the interior fen had the highest emissions from pools, which was consistent with the land-based data. However, the emissions from the coastal fen were about 2 orders of magnitude lower. 

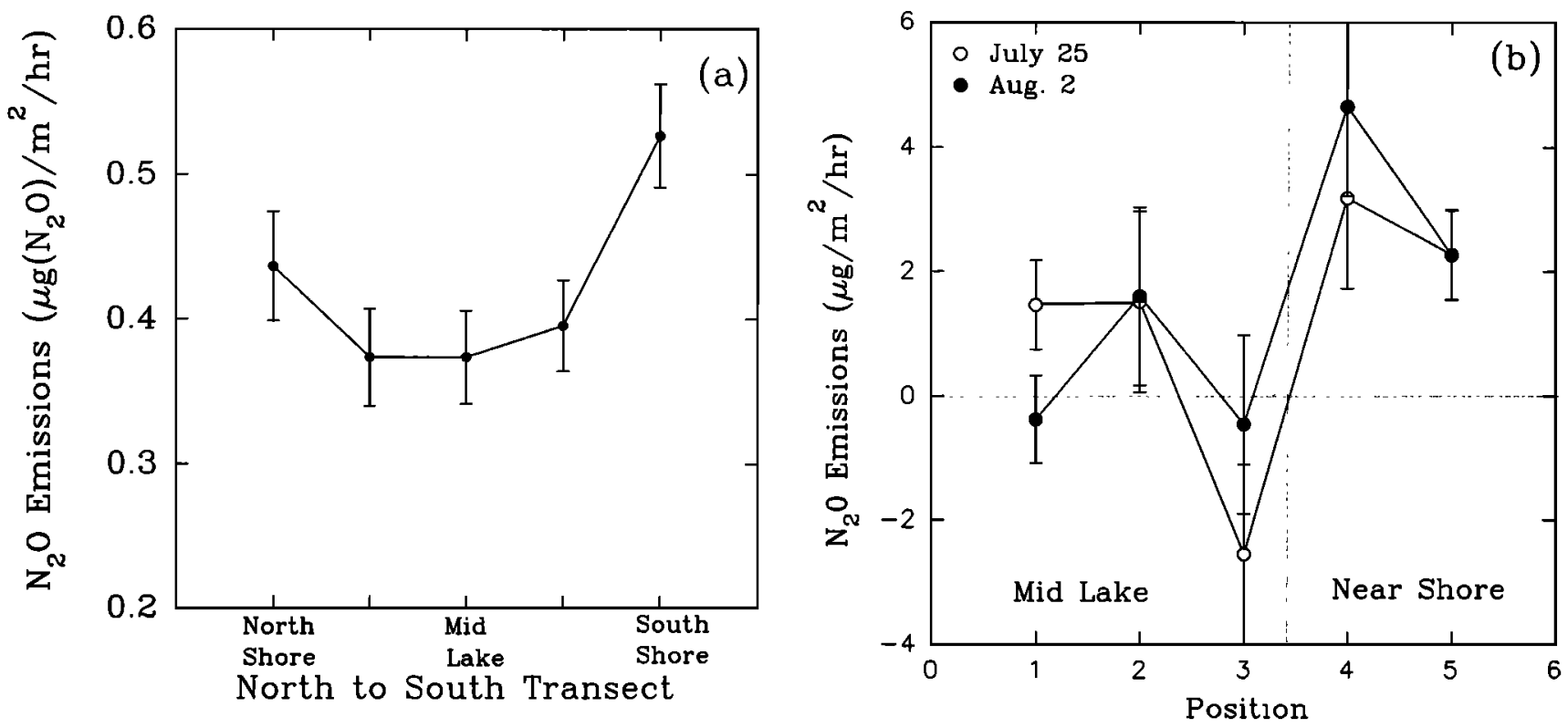

Fig. 9 Change in the emission rate of $\mathrm{N}_{2} \mathrm{O}$ with position in the pool using (a) the gas exchange technique and (b) the chamber technique.
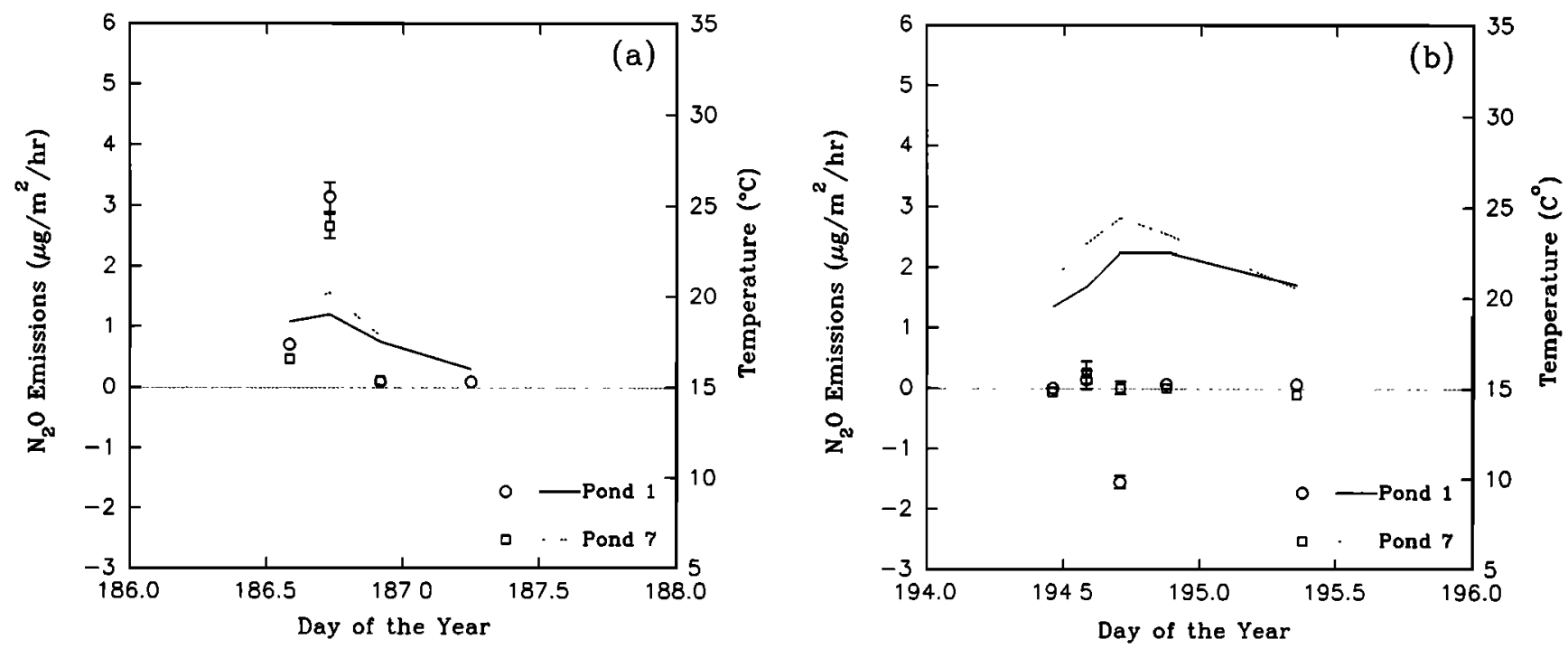

Fig. 10 Comparison of the diumal variation from two ponds at the Kinosheo Lake tower site on days 187 and 195: (a) contains the emission rate and temperature from day 187 and $(b)$ contains the emission rate and temperature from day 195.

Transect. A combination of the chamber measurements and high-resolution Landsat TM data were used to deduce the $\mathrm{N}_{2} \mathrm{O}$ fluxes along a transect from North Point, on the coast of the James Bay, inland $120 \mathrm{~km}$ to Kinosheo Lake. This transect information was used, primarily, in the determination of the effect of ecological succession on the $\mathrm{N}_{2} \mathrm{O}$ emission rate. However, it also provided indications on the sensitivity of the calculated emissions to the methodology described above, particularly on the way in which episodic emissions and the averaging of the open fen data were handled. The transect was broken into twenty-four $5 \times 40 \mathrm{~km}$ strips running parallel to the James Bay coast, and the fraction of each of the 10 ecosystem classes shown in Table 4 within each strip were determined. Figure 11, shows the annual $\mathrm{N}_{2} \mathrm{O}$ emission fluxes calculated along the transect from North Point to Kinosheo Lake. Both the diffusive only and the diffusive plus episodic fluxes are shown, revealing a five-fold increase in the calculated flux when episodic emissions were included. Including the episodic emissions as encountered or averaging them across all classes had little effect on the final fluxes. This is because within any one strip, classes that showed high and low episodic emission frequencies are distributed similarly to those in the area studied.

Figure 12 demonstrates the impact, on the calculated emission rates, of the way in which the open fen fluxes were included. Table 4 shows that there was a large difference between the open fen emissions at the coastal and interior fens, with the coastal fen being much less productive. Since, for most of the $120-\mathrm{km}$ transect, the fens were noncoastal, a simple averaging of the emissions from the two open fen sites would underestimate the emission fluxes. Consequently a weighting was done by location. From the coastal fen site $(\sim 15 \mathrm{~km}$ inland) to the coast the emission values from the coastal fen were used, while inland from the interior fen site $(\sim 25 \mathrm{~km}$ inland) the flux values from the interior fen site were used. Between the two sites a weighted 


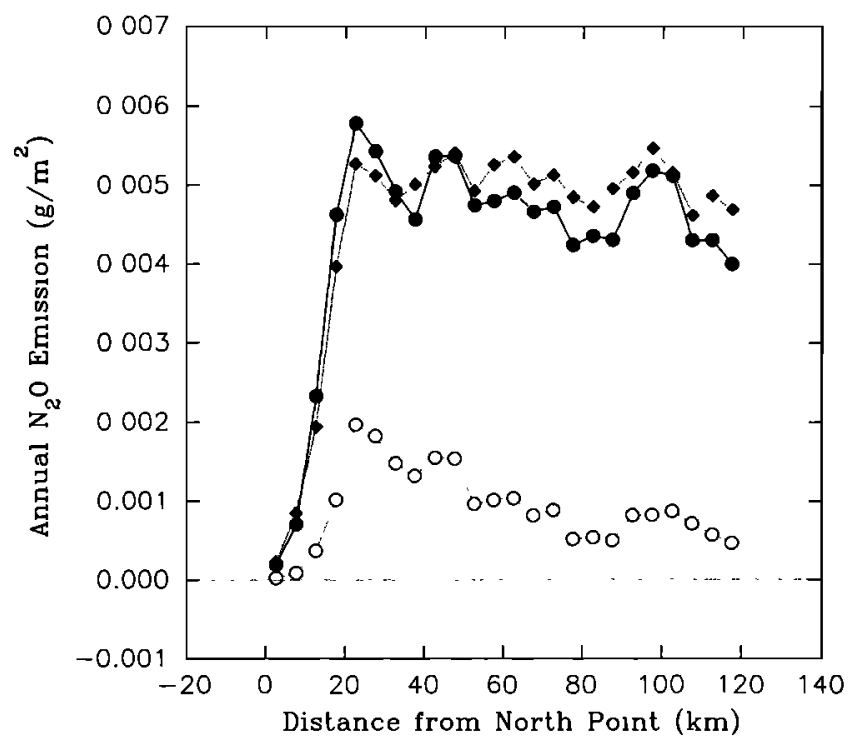

Fig. 11 Annual emission rate of $\mathrm{N}_{2} \mathrm{O}$ along a transect from North Point, on the James Bay coast to Kinosheo Lake. The solid circles represent the emissions of $\mathrm{N}_{2} \mathrm{O}$ with the high episodic emissions included; the open circles represent the diffusive component of the emissions; and the diamonds represent the diffusive component plus a mathematically determined episodic emission rate to account for possible undersampling.

average by distance was calculated. This weighting resulted in 20 to $50 \%$ higher emissions along the transect. Given that the coastal fen type ecosystem had a lower emission rate and covered a smaller area than the interior fen, we felt that the distanceweighted average in Figure 12 was the best representation of the emissions.

The entire $\mathrm{HBL}$ is in isostatic rebound, at a rate of $1 \mathrm{~m} / 100 \mathrm{yr}$ [Mortsch, 1990], so the distance from the coast is a direct measure of the age of the wetland. Figure 12 reveals that the greatest change in the $\mathrm{N}_{2} \mathrm{O}$ emission fluxes occurred in the first $20 \mathrm{~km}$, which in ecological terms was a change from a marsh to a fen type ecosystem. The peak emission occurred in the area where there was the highest proportion of fens, 20 to $50 \mathrm{~km}$ from the coast. In the case of diffusive transport only, there was a decrease in the emissions of $\mathrm{N}_{2} \mathrm{O}$ as the wetland succeeds into a mature bog whereas after the inclusion of the episodic emissions the total emissions remain relatively constant with increasing peat accumulation. This suggests that the episodic emissions become more important as the wetland matures.

Hudson Bay lowland emission estimate. The final scaling up involved the integration of the $\mathrm{N}_{2} \mathrm{O}$ emission fluxes over the entire Hudson Bay lowland, using somewhat lower-resolution Landsat TM data than was used for the transect. In this case, the difference between bogs and bogs with pools were indistinguishable as were open and shrub rich bogs. Therefore the previous 10 categories were reduced to only six. The Landsat TM data from the transect showed that open bogs with pools make up $31 \%$ of the open bog area and open fens with pools make up $41 \%$ of the distinguishable open fen area, and these values were used to determine an area-weighted average emission flux for the open bogs and fens. The shrub rich bog and the open bog were found to be relatively equal in area, so a flux was determined by averaging the fluxes from these sites, before being combined with the emissions from the bogs with pools. A detailed explanation of this scaling up is described by Roulet et al. [this issue]. The resulting fluxes that were used in

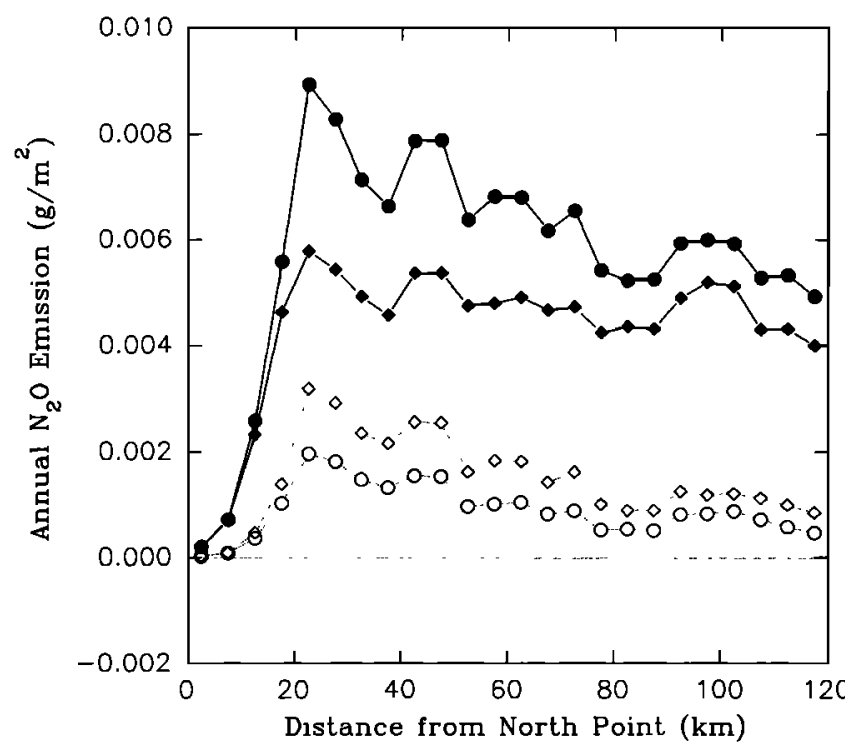

Fig. 12 Annual emission rate of $\mathrm{N}_{2} \mathrm{O}$ along a transect from North Point, on the James Bay coast to Kinosheo Lake. The diamonds contain the emissions from diffusive transport alone, while the circles contain the emissions which include the high episodic component. The solid circles and solid diamonds represent the emissions when simply averaging the open fen sites at the coastal fen and the interior fen, while the open circles and open diamonds represent a weighted averaging of the two sites.

determining the $\mathrm{N}_{2} \mathrm{O}$ fluxes over the entire Hudson Bay lowland are found in Table 6 . These are again split into diffusive transport and those that include both a diffusive and an episodic transport mechanism.

The total annual emissions of $\mathrm{N}_{2} \mathrm{O}$ from the six different ecosystems and the total HBL estimate are shown in Figure 13. The largest fluxes were from the open fen and open bog both in the presence and in the absence of the episodic emissions. The flux from the treed bog ecosystem, when the episodic events were not included, were clearly negative, while inclusion of these events resulted in the exchange rate of $\mathrm{N}_{2} \mathrm{O}$ being very close to zero. The magnitude of this uptake of $\mathrm{N}_{2} \mathrm{O}$, in the absence of the episodic emissions, was equal to half of the total emissions from all other sites combined, which resulted in a very low total emission value for the HBL based on diffusive transport alone.

TABLE 6. The $\mathrm{N}_{2} \mathrm{O}$ Emissions from Six Ecological Classifications Used for the Hudson Bay Lowland Estimate

$$
\text { Annual } \mathrm{N}_{2} \mathrm{O} \text { Emission, Annual } \mathrm{N}_{2} \mathrm{O} \text { Emission, }
$$$$
\mathrm{mg} / \mathrm{m}^{2} \text {, } \mathrm{mg} / \mathrm{m}^{2} \text {, }
$$

Ecosystem Type With Episodic Events Without Episodic Events

\begin{tabular}{lll} 
1. Marsh & 3.8 & 0.4 \\
2. Open fen & 8.9 & 4.3 \\
3. Treed fen & 4.2 & 0.5 \\
4. Open bog & 5.2 & 0.7 \\
5. Treed bog & 0.1 & -2.7 \\
6. Conifer forest & 1.2 & 1.2 \\
$\begin{array}{c}\text { Total Emissions, } \\
\text { Gg/yr }\end{array}$ & 1.2 & 0.2 \\
\hline
\end{tabular}




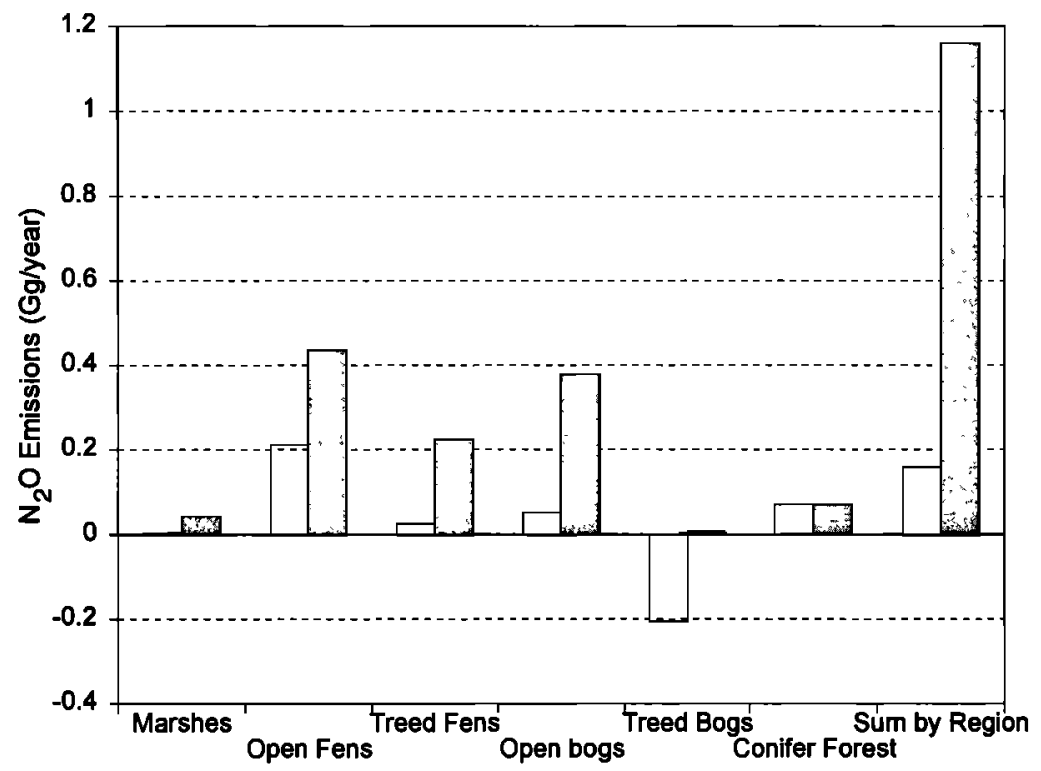

Fig. 13 Total annual emissions of $\mathrm{N}_{2} \mathrm{O}$ within the Hudson Bay lowlands broken down by the six ecological classifications. The open bars represent the diffusive component of the emissions only, while the shaded bars represent the emissions when the high episodic emissions are included.

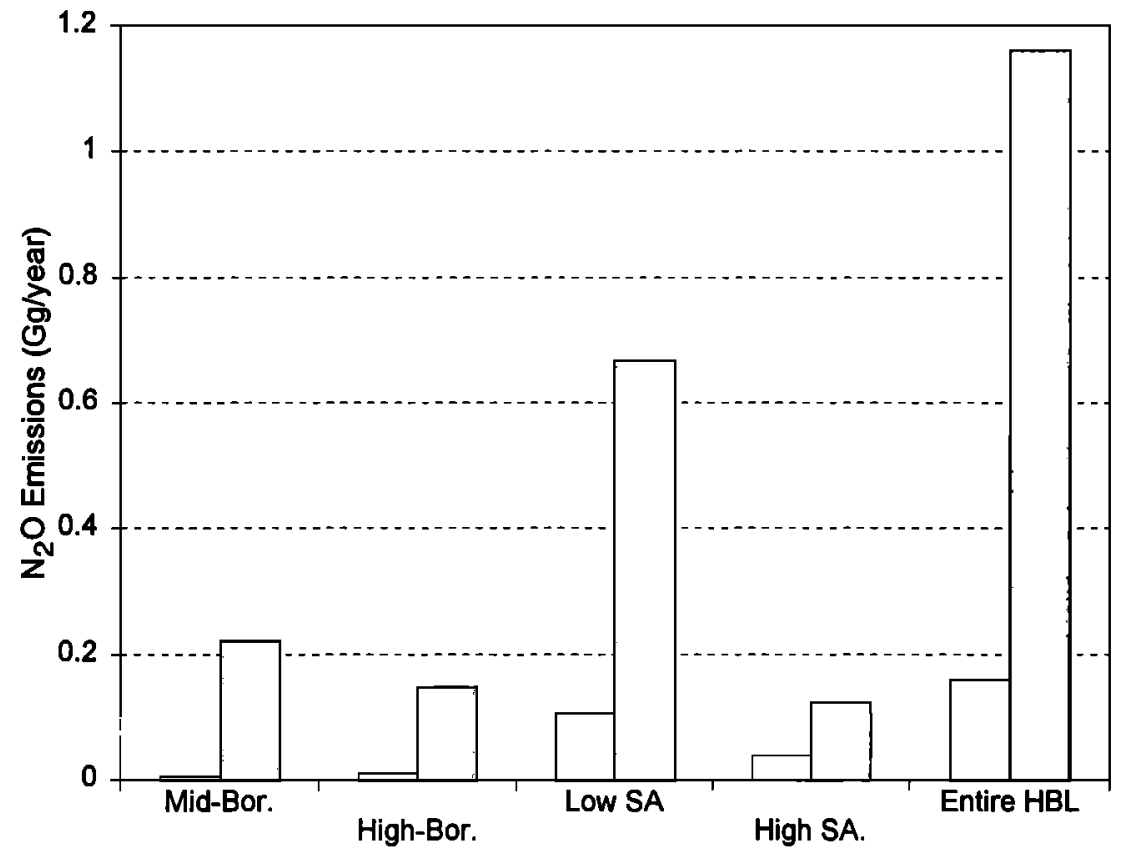

Fig. 14 Total annual emissions of $\mathrm{N}_{2} \mathrm{O}$ within the Hudson Bay lowland, broken down into the four geographical regions. The open bars represent the diffusive component of the emissions only, while the shaded bars represent the emissions when the high episodic emissions are included.

This indicates that northern boreal forests could be likely sinks for nitrous oxide.

Since all measurements were taken in a wetland region that divides the low subarctic region from the midboreal region and since the majority of the subarctic region was considerably north of the study location, there was concern that using the fluxes measured here, the total emissions from the Arctic regions may be overestimated. The relative contributions of the four distinguishable regions, low subarctic, high subarctic, midboreal, and high boreal regions, to the HBL emissions were determined so that should a better estimate from these regions become available, the emissions from the Hudson Bay lowland could be readily updated. Figure 14 contains the breakdown of the emissions of $\mathrm{N}_{2} \mathrm{O}$ within these regions. This clearly indicates that the emissions from the low subarctic region account for over half of the total emissions from the Hudson Bay lowland.

The total emissions of $\mathrm{N}_{2} \mathrm{O}$ from the Hudson Bay lowland, based on diffusive transport alone, was $0.2 \mathrm{Gg} / \mathrm{yr}$. The inclusion of the episodic emissions increased this value to $1.2 \mathrm{Gg} / \mathrm{yr}$, six times the diffusion-based estimate, which emphasized the importance of these episodic events on the emissions from a northern wetland environment. The estimates for the emission from natural soils were (in $\mathrm{Tg}\left(\mathrm{N}_{2} \mathrm{O}\right) / \mathrm{yr}$ ) 31.4 [Warneck, 1988], 18.8 [Mosier and Schimel, 1991], 16 [Davidson, 1991], and 8 to 79 [Banin, 1986]. Thus the emissions of $\mathrm{N}_{2} \mathrm{O}$ from the northern wetlands account for on the order of $0.002 \%$ to $0.02 \%$ of the 
total estimated soil emissions, or on the order of $0.0005 \%$ to $0.005 \%$ of the global $\mathrm{N}_{2} \mathrm{O}$ production. On a global scale, this means that the emissions of nitrous oxide from the Hudson Bay lowland are insignificant. However, more important was the fact that these low emission fluxes were influenced by an uptake of nitrous oxide within treed bog areas. At present, in most nitrous oxide budgets the source strength is too high (or the sink strength is too low), the fact that the Hudson Bay lowland is a very small source points to the possibility that other treed wetland areas may be part of the missing sink of $\mathrm{N}_{2} \mathrm{O}$.

\section{CONClusion}

The emissions of nitrous oxide in the Hudson Bay lowland were dominated by the emissions from the open fen regions, while the treed areas produced the lowest emissions, or uptake. Although there does appear to be a weak temperature dependence, the large variability of the emission fluxes mask this in the majority of the sites. This was also true for the lack of a diurnal variation. There was a seasonal variation for the emission of $\mathrm{N}_{2} \mathrm{O}$, with most sites showing a summer maximum but the treed areas showing a coinciding minimum during the warmest part of the growing season.

The differences in the emissions between similar ecosystems at separate sites could be larger than those differences between separate ecosystems within a site. In the open fens the emission rates from the interior fen were almost a factor of 10 higher than those from the coastal fen. These two sites were indistinguishable by remote sensing, and therefore any extrapolation of ground-based data, using remote sensing, must be interpreted with care.

The emissions from the Hudson Bay lowland were of the order of $1.2 \mathrm{Gg} / \mathrm{yr}$. Of this, approximately $80 \%$ were the result of an episodic type transport mechanism which was likely ebullition. This indicates that since $80 \%$ of the total exchange was due to an episodic type process, which was seen in less than $5 \%$ of the total samples, it was very important to have a large sample size in order to obtain a representative sampling of the emissions of this sort. In addition, of the order of $30 \%$ of the different vegetation types exhibited uptake of nitrous oxide, while all vegetative sites exhibited uptake for part of the growing season. In particular, the treed bog regions exhibited significant uptake, which could indicate that another possible sink for nitrous oxide is treed wetland areas.

Acknowledgments. We would like to thank Andrew Jano of the Ontario Centre for Remote Sensing at the Ontario Ministry of Natural Resources for the remote sensing data, Carol Kelly, John Rudd, and Dave Hamilton for their informative discussions and scientific support, and a special thanks to Nigel Roulet, whose discussions, technical, and scientific support were invaluable. We would also like to thank the reviewers whose comments, criticisms, and suggestions were most helpful. This is scientific contribution 92-4 of the Canadian Institute for Research in Atmospheric Chemistry (CIRAC). The work described herein was undertaken as a part of the CIRAC Northern Wetlands Study which has been generously supported by the Natural Sciences and Engineering Research Council of Canada. Although the research described in this article has been carried out under the auspices of CIRAC, it reflects only the views of the authors and does not necessarily reflect the official views of CIRAC.

\section{REFERENCES}

Banin, A. Global budget of $\mathrm{N}_{2} \mathrm{O}$ : The role of soils and their change, Sci. Total Environ. ,55, 27-38, 1986.

Bartlett, K.B., P.M. Crill, D.I. Sebacher, R.C. Harriss, J.O. Wilson, and J.M. Melack, Methane flux from the central Amazon flood plain, $J$. Geophys. Res., 93, 1571-1582, 1988.
Biermann, H.W., C. Zetzsch, and F.Stuhl, Rate constant for the reaction of $\mathrm{OH}$ with $\mathrm{N}_{2} \mathrm{O}$ at $298 \mathrm{~K}$, Ber. Bunsen Ges. Phys. Chem., 80, 909$911,1976$.

Blackmer, A.M., and J.M. Bremner, Potential of soil as a sink for atmospheric nitrous oxide, Geophys. Res. Lett., 3, 739-742, 1976.

Blackmer, A.M., S.G. Robbins, and J.M. Bremner, Diurnal variability in rate of emission of nitrous oxide from soils, Soil Sci. Soc. Am. J., 46, 937-942, 1982.

Bowden, R.D., J.M. Milillo, P.A. Steudler, and J. D. Aber, Effects of nitrogen additions on annual nitrous oxide fluxes from temperate forest soils in the northeastem United States, J. Geophys. Res., 96, 93219328, 1991.

Cates Jr., R.L., and D.R. Keeney, Nitrous oxide emissions from native and reestablished prairies in southem Wisconsin, Am. Midl. Nat., 117, 35-42, 1987.

Chanton, J.P., and C.S. Martens, Seasonal variations in ebbulitive flux and carbon isotopic composition of methane in a tidal freshwater estuary, Global Biogeochem. Cycles, 2, 289-298, 1988.

Cicerone, R.J. Analysis of sources and sinks of atmospheric nitrous oxide $\left(\mathrm{N}_{2} \mathrm{O}\right), J$. Geophys. Res., 94, 18,265-18,271, 1989.

Crusius, J. and R.H. Wanninkhof, Refining the gas exchange - Wind speed relationship at low wind speeds on lake $302 \mathrm{~N}$ with $\mathrm{SF}_{6}$, Limn. Oceanogr., 1991.

Davidson, E.A., Fluxes of nitrous oxide and nitric oxide from terrestrial ecosystems, in Microbial Production and Consumption of Greenhouse Gases: Methane, Nitrogen Oxides and Halomethanes, edited by J.E. Rogers and W.B. Whitman, pp 219-235, American Society for Microbiology, Washington, D. C., 1991.

Denmead, O.T., Chamber systems for measuring nitrous oxide emissions from soils in the field, Soil Sci. Soc. Am. J., 43, 89-95, 1979.

Devol, A.H., J.E. Richey, W.A. Clark, S.L. King and L.A. Martinelli, Methane emissions to the troposphere from the Amazon flood plain, J. Geophys. Res., 93, 1583 - 1592, 1988.

Goodroad, L.L., and D.R. Keeney, Nitrous oxide emission from forest, marsh and prairie ecosystems, J. Environ. Qual., 13, 448-452, 1984.

Goodroad, L.L., D.R. Keeney, and L.A. Peterson, Nitrous oxide emissions from agricultural soils in Wisconsin, J. Environ. Qual., 13, $557-561,1984$.

Himmelblau, D.M., Diffusion of dissolved gases in liquids, Chem. Rev., $64,527-550,1964$.

Jury, W.A., J. Letey, and T. Collins, Analysis of chamber methods used for measuring nitrous oxide production in the field, Soil Sci. Soc. Am. $J ., 46,250-256,1982$.

Kwan, J. and P. Taylor, On gas fluxes from small lakes and ponds, Boundary Layer Meteorol., in press.

Liss, P.S., and L. Merlivat, Air-sea exchange Rates: Introduction and synthesis, P. Buat-Ménard (ed) in The role of Air-Sea exchange in Geochemical Cycling, pp 113-127, D. Reidel, 1986.

Matson, P.A., P.M. Vitousek, G.P. Livingston, and N.A. Swanberg, Sources of variation in nitrous oxide flux from Amazonian ecosystems, J. Geophys. Res., 95, 16,789-16,798, 1990.

McElroy, M.B. and S.C. Wofsy, Tropical forests: Interactions with the atmosphere, in Tropical Rain Forests and the Worlds Atmosphere edited by G.T. Prance, pp 33-60,, Westview, Boulder, Colo., 1986.

Mortsch, L., (Ed.), Eastern Canadian boreal and subarctic wetlands: A resource document (ECBS-AW), in Environ. Can., Climatol. Stud. 42, p 58, 1990.

Mosier, A.R., and D.S. Schimel, Influence of agricultural nitrogen on atmospheric methane and nitrous oxide, Chem. and Ind., 23, 874-877, 1991.

National Wetlands Working Group (NWWG), Canada's Wetlands: Maps of wetland regions and distribution in Canada, Lands Dir., Environ. Can., Ottawa: 2 maps at 1:7.5 m scale plus fact sheet, 1986.

Pearman, G.J., D. Etheridge, F. de Silva, and P.J. Fraser, Evidence of changing concentrations of atmospheric $\mathrm{CO}, \mathrm{N}_{2} \mathrm{O}$ and $\mathrm{CH}_{4}$ from air bubbles in Antarctic ice, Nature, 320, 248- 250, 1986.

Prinn, R., D. Cunnold, R. Rasmussen, P. Simmonds, F. Alyea, A. Crawford, P. Fraser, and R. Rosen, Atmospheric emissions and trends of nitrous oxide deduced from 10 years of ALE-GAGE Data, $J$ Geophys. Res., 95, 18,369-18,385, 1990.

Ramanathan, V., R.J. Cicerone, H.B. Singh and J.T. Kiehl, Trace gas trends and their potential role in climate change, J. Geophys. Res., 90, 5547-5566, 1985.

Riley, J.L., Hudson Bay Lowland floristic inventory, wetlands catalogue and conservation strategy.Le Naturaliste Can., Que., 109, 543-555, 1982. 
Rosswall, T., et al., Group report: What regulates production and consumption of trace gases in ecosystems: Biology or physiochemistry?, in Exchange of Trace Gases Between Terrestrial Ecosystems and the Atmosphere, pp 73-95, Life Sciences Research Report 47, Wiley Interscience, 1989.

Roulet, N.T., A. Jano, C.A. Kelly, L. Klinger, T.R. Moore, R. Protz J. Ritter, and W.R. Rouse, The role of the Hudson Bay lowland as a source of atmospheric methane, $J$. Geophys. Res., this issue.

Ryden, J.C., $\mathrm{N}_{2} \mathrm{O}$ exchange between a grassland soil and the atmosphere, Nature, 292, 235-237, 1981.

Seiler, W.A., H. Giehl, and G. Bunse, Influence of plants on atmospheric carbon monoxide and dinitrogen oxide, Pure Appl. Geophys., 116, 439-451, 1978.

Shepherd, M.F., S. Barzetti, and D.R. Hastie, The production of atmospheric $\mathrm{NO}_{\mathrm{x}}$ and $\mathrm{N}_{2} \mathrm{O}$ from fertilized agricultural soil, Atmos. Environ., 25, 1961-1969, 1991.

Smith, C.J., D.R. DeLaune, and W.H. Patrick, Jr., Nitrous oxide emission from Gulf Coast wetlands, Geochim. Cosmochim. Acta, 47 $1805-1814,1983$

Urban, N.R., S.J. Eisenreich, and S.E. Bayley, The relative importance of denitrification and nitrate assimilation in midcontinental bogs, Limnol. Oceanogr., 33, 1611-1617,1988.

Wanninkhof, R., J.R. Ledwell, and W.S. Broecker, Gas exchange-wind speed relation measured with sulfur hexafluoride on a lake, Science, 227, 1224-1226, 1985.

Wameck, P., Chemistry of the Natural Atmosphere, Int. Geophys. Ser., vol 41, Academic, san Diego, Calif., 1988.

Wilhelm, E., R. Battino, and R. Wilcock, Low-pressure solubility of gases in liquid water, Chem. Rev., 77, 219-262, 1977

Wilson, J.O., P.M. Crill, K.B. Bartlett, D.I. Sebacher, R.C. Harriss, and R.L. Sass, Seasonal variation of methane emissions from a temperate swamp, Biogeochemistry, 8, 55-71, 1989.

D.R. Hastie and C.L. Schiller, Department of Chemistry, and Centre for Atmospheric Chemistry, York University, 4700 Keele Street, North York, Ontario, Canada, M3J 1P3.

(Received January 29, 1993; revised May 13, 1993;

accepted May 18, 1993.) 